\title{
Examining the influence of biophysical conditions on wildland-urban interface homeowners' wildfire risk mitigation activities in fire-prone landscapes
}

\author{
Christine S. Olsen $^{1}, \underline{\text { Jeffrey D. Kline }}^{2}, \underline{\text { Alan A. Ager }}^{3}, \underline{\text { Keith A. Olsen }}^{1}$ and $\underline{\text { Karen C. Short }}^{3}$
}

\begin{abstract}
Expansion of the wildland-urban interface (WUI) and the increasing size and number of wildfires has policy-makers and wildfire managers seeking ways to reduce wildfire risk in communities located near fire-prone forests. It is widely acknowledged that homeowners can reduce their exposure to wildfire risk by using nonflammable building materials and reducing tree density near the home, among other actions. Although these actions can reduce the vulnerability of homes to wildfire, many homeowners do not take them. We examined the influence of risk factors on homeowners' perceived wildfire risk components using a survey of WUI homeowners in central Oregon (USA) and biophysical data that described wildfire risk as predicted by wildfire simulation models, past wildfire, and vegetation characteristics. Our analysis included homeowners' perceptions of the likelihood of wildfire and resulting damage, and examined how these factors contribute to homeowners' likelihood to conduct mitigation actions. We developed an empirical model of homeowners' risk perceptions and mitigation behavior, which served as input into an agent-based model to examine potential landscape and behavior changes over 50 years. We found homeowners' wildfire risk perceptions to be positively correlated with hazardous conditions predicted by fuel models and weakly predictive of mitigation behavior. Homeowners' perceived chance of wildfire was positively correlated with actual probability of wildfire, while their perceived chance of damage to the home was positively correlated with potential wildfire intensity. Wildfire risk perceptions also were found to be correlated with past wildfire experience. Our results suggest that homeowners may be savvy observers of landscape conditions, which act as "feedbacks" that enhance homeowners' concerns about wildfire hazard and motivate them to take mitigation action. Alternatively, homeowners living in hazardous locations are somehow receiving the message that they need to take protective measures. Mitigation compliance output from the agent-based model suggests that completion of mitigation actions is likely to increase over 50 years under various scenarios.
\end{abstract}

Key Words: defensible space; Firewise; hazard; risk; wildfire exposure; wildland-urban interface

\section{INTRODUCTION}

The area of land burned by wildfire in the United States has increased dramatically in recent years, particularly in the west, where high fuel loads have also contributed to more severe fires (USDA Forest Service 2009, Short 2015). The number of private homes located in forested areas and in the wildland-urban interface (WUI) has also increased, bringing greater numbers of people and structures into fire-prone landscapes (Radeloff et al. 2005). The increasing size and occurrence of wildfires, coupled with greater numbers of houses at risk, are leading factors that are causing suppression expenditures to increase (Liang et al. 2008), which have totalled more than US\$1 billion annually for 13 of the past 15 years among the federal agencies alone (National Interagency Fire Center 2014). Managers and policy-makers are thus searching for ways to reduce wildfire risk in fire-prone areas. Although the total area of land owned by individual homeowners is a small fraction of most landscapes compared to other types of landowners - federal and private industrial, for exampleprivately owned home sites tend to receive a disproportionately large share of wildfire suppression effort when wildfires occur (USDA OIG 2006, Gebert et al. 2007, Liang et al. 2008).

However, suppressing active wildfires is not the only way to save homes and lives. In fact, Calkin et al. (2014) argue that the emphasis on fire suppression has exacerbated the WUI fire problem by framing it as a wildfire control failure "instead of focusing on the susceptibility of structures to the inevitability of wildfire exposure." Private homeowners can undertake effective actions at the home site to mitigate wildfire risk, such as using fire-resistant building materials, clearing roofs and gutters of tree needles and debris, and reducing vegetation around the home, all of which reduce the possibility of potential damages and losses (GAO 2005). Indeed, home ignitability_-something a homeowner can influence through such mitigation actions - is a principal determining factor in private property losses owing to wildfire (Syphard et al. 2014). For this reason, policy-makers and local officials have emphasized the importance of increasing such actions among homeowners located in fire-prone areas.

A number of studies have suggested that homeowners located in fire-prone wildland-urban interface areas tend to understand that their homes are at risk of wildfire and do conduct at least some risk mitigation activities as a result (e.g., Nelson et al. 2004, Brenkert-Smith et al. 2006, McCaffrey 2008, Steelman 2008, Kyle et al. 2010, Dickinson et al. 2015). These findings appear to be consistent across geographic locations and different research methodologies (McCaffrey and Olsen 2012). However, many homeowners still do not take mitigation actions; hence, efforts to better understand what factors influence mitigation behavior continue.

We build on previous research pertaining to the wildfire risk perceptions and mitigation activities of homeowners in fire-prone landscapes by examining the role of biophysical (or "modeled") wildfire risk factors in influencing wildfire risk perceptions and risk mitigation behaviors. We use the word modeled as others have

${ }^{1}$ Forest Ecosystems \& Society, Oregon State University, ${ }^{2}$ USDA Forest Service, Pacific Northwest Research Station, ${ }^{3}$ USDA Forest Service, Rocky Mountain Research Station 
used the word "objective" in prior research efforts - to describe risk factors that are based on modeled biophysical variables (e.g., Fischer et al. 2014). Specifically, we (1) identify biophysical and socioeconomic factors that influence homeowners' wildfire risk perceptions and their likelihood to mitigate risk, and (2) demonstrate how such information can be used to anticipate where homeowners are mostly likely to conduct risk mitigation activities. Toward this second objective, our analysis provides empirical parameters to an agent-based model (Envision) for predicting homeowners' mitigation responses to hypothetical wildfire risk management scenarios, as part of a coupled human and natural systems (CHANS) study examining the management of wildfire risk in a fire-prone landscape of central Oregon (USA) (Spies et al. 2014, Spies et al. 2017). This approach of employing an agent-based model that combines social and biophysical data allows us to examine possible future trends of homeowner mitigation behavior in response to the changing ecological landscape under different climate and management scenarios. To our knowledge, such an attempt at predicting future mitigation behavioral trends has not been attempted. Data to address our objectives were gathered using a survey of homeowners living in WUI locations in central Oregon, which described their perceptions of wildfire risk, including the likelihoods of both wildfire and resulting damage to the home, as well as factors hypothesized to influence homeowners' propensity to conduct mitigation activities. We combined these data with biophysical data that described modeled wildfire risk, past wildfire, and vegetation characteristics to estimate an empirical model of homeowners' perceptions of wildfire risk components, and their combined influence on mitigation behavior. We used this empirical model to develop a predictive equation that described homeowners' likelihoods to conduct risk mitigation activities, which served as a decision rule in an agent-based model to account for homeowners' responses to landscape conditions and wildfires under hypothetical forest management and climate scenarios. Our results have implications for anticipating which homeowners are most likely to conduct mitigation activities, devising policy or programmatic efforts to encourage greater mitigation activity among homeowners not yet engaged, and developing approaches for predicting future coupled homeowner and landscape behavior.

\section{Conceptual foundation}

For most hazards, including wildfire, higher perceptions of risk among individuals generally are believed to be associated with individuals' greater desire to reduce their exposure to risk (e.g., McCaffrey 2006). This largely has been confirmed by studies that have examined landowners' and homeowners' self-reported perceptions of their own general level of exposure to wildfire risk (McCaffrey et al. 2011, Champ et al. 2013, Fischer et al. 2014, Dickinson et al. 2015). Protection Motivation Theory also suggests that individuals are more likely to mitigate risk for threatening events based on their perceptions of the probability and severity of an event and associated outcomes (risk perceptions) and their ability to take protection actions (Rogers 1983). This perspective is reflected in studies that have examined perceived wildfire risk and its influence on mitigation behavior in terms of individual risk components: wildfire likelihood and potential wildfire severity (Hall and Slothower 2009, McCaffrey et al. 2011, McNeill et al. 2013, Dickinson et al. 2015). However, recent research also suggests merit in considering the role of modeled or objective wildfire risk in shaping wildfire risk perceptions (Fischer et al. 2014).

\section{Wildfire risk}

Risk generally is defined as the multiplication of the probability of an event occurring with the negative outcomes of that event if it occurred (Kasperson et al. 1988, Renn et al. 1992). In the case of wildfire, objective risk as described by fire experts is comprised of the technical probability of a wildfire occurring and the severity of the wildfire if it occurs (Ager et al. 2013). However, also relevant from a public policy standpoint is perceived risk, which is comprised of an individual's perceived probability of a wildfire occurring and the perceived severity of the wildfire if it occurs (Martin et al. 2009). Homeowners tend to consider the wildfire risk to their property as lower than the wildfire risk to surrounding landscapes in fire-prone areas (McCaffrey 2008). Overall, although public perceptions of wildfire risk maybe multifaceted and complex, it has been suggested that many managers believe that homeowners do not take risk mitigation actions simply because they misunderstand biophysical risk (Gordon et al. 2012). Several factors have been found to influence individuals' wildfire risk perceptions, including modeled measures of biophysical risk. In one study of private nonindustrial forest landowners in eastern Oregon, survey respondents' wildfire risk perceptions were found to be correlated with actual hazardous fuel conditions on the ground as measured by the potential for crown fire in the vicinity of respondents' parcels (Fischer et al. 2014), as well as past experiences with wildfire and other factors. Others have also found positive relationships between past wildfire experiences and risk perception (Cohn et al. 2008, Gordon et al. 2012). Contact with certain information sources also has been correlated with perceived wildfire risk. Specifically, the local fire department, county fire specialists, and neighbors and friends as information sources are positively associated with an increase in homeowners' perceived likelihood of wildfire, while only neighbors and friends as information sources are positively associated with an increase in homeowners' perceived consequences from wildfire (BrenkertSmith et al. 2013, Dickinson et al. 2015).

\section{Factors influencing mitigation behavior}

Risk perceptions alone typically are not the only factor that has an influence on individuals' risk mitigation decisions (Showalter 1993, Lindell and Prater 2000), and this seems to be the case with wildfire (Cortner and Gale 1990, McCaffrey 2004). Champ et al. (2013), for example, suggest that homeowners' wildfire risk perceptions and mitigation decisions are jointly determined by a combination of characteristics pertaining to homeowners and their home sites. Research, however, has not found a consistent association between wildfire risk and actual mitigation behavior on private land, with some studies finding a positive association (e.g., Nelson et al. 2004, Martin et al. 2009, McCaffrey et al. 2011, Brenkert-Smith et al. 2012, McNeill et al. 2013, Dickinson et al. 2015) and others finding no association or better explanations using other variables (e.g., Nelson et al. 2005, Hall and Slothower 2009, Schulte and Miller 2010). An explanation may be in the variety of ways that researchers have measured mitigation behavior, ranging from a yes/no question about whether homeowners have conducted mitigation activities generally, to separate measurements and analysis for several individual mitigation actions, including clearing brush near the home or using fire-resistant building materials (Table 1). The variety of 
Table 1. Review of recent quantitative studies that modeled homeowner fire risk mitigation behavior.

\begin{tabular}{|c|c|c|c|c|c|}
\hline Authors and year & Study area location & $\begin{array}{l}\text { Survey } \\
\text { response } \\
\text { rate† }\end{array}$ & $\begin{array}{l}\text { Mitigation } \\
\text { measurement } \\
\text { method }\end{array}$ & $\begin{array}{l}\text { Tested factors influencing mitigation behavior (all } \\
\text { statistically significant; others were tested) }\end{array}$ & $\begin{array}{c}\text { Biophysical } \\
\text { variables tested? }\end{array}$ \\
\hline $\begin{array}{l}\text { Bihari and Ryan } \\
\text { (2012) }\end{array}$ & $\begin{array}{l}\text { Montana, Colorado, } \\
\text { New Mexico, } \\
\text { California, Florida, } \\
\text { New Jersey (USA) }\end{array}$ & $43 \%$ & Groups & Community cohesion & No \\
\hline $\begin{array}{l}\text { Brenkert-Smith et } \\
\text { al. (2012) }\end{array}$ & Colorado (USA) & $36 \%$ & Number & $\begin{array}{l}\text { Lot size, age, money, perceived risk, wildfire } \\
\text { experience, efficacy, wildfire information sources and } \\
\text { social interactions }\end{array}$ & No \\
\hline $\begin{array}{l}\text { Bright and Burtz } \\
(2006)\end{array}$ & Minnesota (USA) & $54 \%$ & Individual & $\begin{array}{l}\text { Membership in individualist/private property group } \\
\text { or nonindividualist/community-oriented property } \\
\text { group }\end{array}$ & No \\
\hline $\begin{array}{l}\text { Champ et al. } \\
\text { (2013) }\end{array}$ & Colorado (USA) & $52 \%$ & Number & $\begin{array}{l}\text { Wood roof, slope near home, perceived risk, income, } \\
\text { age, previously accessed local Firewise website, } \\
\text { previously owned home in an area at risk of wildfire }\end{array}$ & Yes, significant \\
\hline Collins (2008) & Arizona (USA) & $50 \%$ & Number & $\begin{array}{l}\text { Amenity values (prefer environment, property fire } \\
\text { prevention, fire suppression capability), housing } \\
\text { tenure, income, retirement status, length of residence, } \\
\text { full-/part-time residency, livelihoods depend on } \\
\text { forests, parcel characteristics (dwelling type and } \\
\text { value) }\end{array}$ & $\begin{array}{l}\text { Yes, not } \\
\text { significant }\end{array}$ \\
\hline $\begin{array}{l}\text { Dickinson et al. } \\
\text { (2015) }\end{array}$ & Colorado (USA) & $36 \%$ & Groups & $\begin{array}{l}\text { Nearby neighbors, receiving information or talking } \\
\text { about fire with neighbors, perceiving neighbors' } \\
\text { property as having dense fuels, attending fire-specific } \\
\text { events or talking with a fire expert, perceived } \\
\text { probability of wildfire, perceived efficacy and } \\
\text { aesthetics of mitigation, needing more information } \\
\text { about mitigation }\end{array}$ & No \\
\hline $\begin{array}{l}\text { Hall and } \\
\text { Slothower (2009) }\end{array}$ & Oregon (USA) & $59 \%$ & Dummy & $\begin{array}{l}\text { Efficacy of mitigation program, general attitude } \\
\text { toward mitigation }\end{array}$ & No \\
\hline Kyle et al. (2010) & California (USA) & $33 \%$ & Groups & $\begin{array}{l}\text { Affective attachment, community tenure, place } \\
\text { identity, place dependence, social bonding, home } \\
\text { tenure }\end{array}$ & No \\
\hline $\begin{array}{l}\text { Martin et al. } \\
(2009)\end{array}$ & $\begin{array}{l}\text { Colorado, Oregon } \\
\text { (USA) }\end{array}$ & $49 \%$ & Number & $\begin{array}{l}\text { Perceived risk, subjective knowledge, responsibility, } \\
\text { full-time or seasonal status, study site location }\end{array}$ & No \\
\hline $\begin{array}{l}\text { McNeill et al. } \\
\text { (2013) }\end{array}$ & Western Australia & $33 \%$ & Groups & $\begin{array}{l}\text { Method of completing survey (paper or online), } \\
\text { gender, age, geographic region, risk severity, } \\
\text { protection responsibility, warning reliability, loss of } \\
\text { services (water, electricity, phone) }\end{array}$ & No \\
\hline $\begin{array}{l}\text { Schulte and } \\
\text { Miller (2010) }\end{array}$ & Colorado (USA) & $54 \%$ & Groups & $\begin{array}{l}\text { Amenity values, motive based on community effort, } \\
\text { neighbor effect, fire-resistant construction, fire- } \\
\text { resistant roof, fire-resistant windows }\end{array}$ & $\begin{array}{l}\text { Yes, not } \\
\text { significant }\end{array}$ \\
\hline $\begin{array}{l}\text { Wolters et al., } \\
\text { personal } \\
\text { communication }\end{array}$ & Oregon (USA) & $48-51 \%$ & Number & $\begin{array}{l}\text { Age, education, familiarity with community wildfire } \\
\text { protection plan, risk perception, proximity to } \\
\text { wildland area, wildfire experience }\end{array}$ & No \\
\hline \multicolumn{6}{|c|}{$\begin{array}{l}\text { †Overall response rate for the survey as reported by the authors. Most analyses excluded some respondents due to unanswered questions, which made } \\
\text { some effective response rates lower. Administration methods varied (e.g., random mail survey, internet survey, drop-off survey). } \\
\text { †"Dummy" = yes or no response to a single general question about completing mitigation activities; "Individual" = yes or no response to multiple } \\
\text { questions about individual mitigation activities;,"Number" = number of individual mitigation activities that respondents indicated completing; } \\
\text { "Groups" = individual actions were lumped into similar groups and then a yes/no response, a number, or a mean of activities within groups or } \\
\text { categories was used. }\end{array}$} \\
\hline
\end{tabular}

ways researchers have measured risk perception has also likely contributed to the range of findings.

Another influencing factor in mitigation behavior has been homeowners' interactions with agencies and organizations involved in wildfire education and outreach (Dickinson et al. 2015), including membership in forestry or fire protection organizations (Fischer et al. 2014), participation in natural resource-related planning efforts (Bihari and Ryan 2012), involvement in homeowner associations in locations where wildfire risk is a concern (McCaffrey et al. 2011), and living in neighborhoods where wildfire mitigation programs have been implemented (McGee et al. 2009). Broader public education and outreach efforts also have been linked with an increased likelihood of mitigation (Schulte and Miller 2010, McCaffrey et al. 2011).

Lastly, the physical (i.e., age) and financial ability (i.e., income) of homeowners to accomplish mitigation actions is another influencing factor examined by previous research, which has yielded mixed results (e.g., Collins 2008, 2009, McFarlane et al. 
2011, Brenkert-Smith et al. 2012, Champ et al. 2013, Fischer et al. 2014). Additional factors found to positively influence mitigation behavior include length of land ownership/residence (hereafter referred to as years at property [Blanchard and Ryan 2007, Collins 2009, Fischer 2011]) and presence of local requirements such as homeowners association rules that mandate mitigation actions (Winter et al. 2009).

\section{Conceptual framework and predicting future behavior}

We examined homeowner mitigation behavior using a conceptual framework informed by the literature, particularly Fischer et al. (2014) and Champ et al. (2013), as well as Protection Motivation Theory (Rogers 1983). Synthesizing this work, we hypothesized that homeowners' perceived wildfire risk is a function of factors such as hazardous fuel conditions near the home site, as well as the homeowners' past experiences with wildfire, and the social context (or networks) in which homeowners' beliefs, attitudes, and norms about wildfire are formed and diffused (Fig. 1). We hypothesize that whether homeowners undertake risk mitigation activities to reduce their exposure to wildfire risk is a function of their perceived wildfire risk, past experiences with wildfire, social context, and whether they are subject to any local requirements to conduct mitigation activities. The conceptual framing thus defines a structural model for empirically testing the influence of various biophysical and socioeconomic factors on homeowners' wildfire risk perceptions and their likelihood of undertaking mitigation activities.

Fig. 1. Conceptual framework describing factors influencing homeowners' perceived wildfire risk and likelihood of conducting mitigation activities.

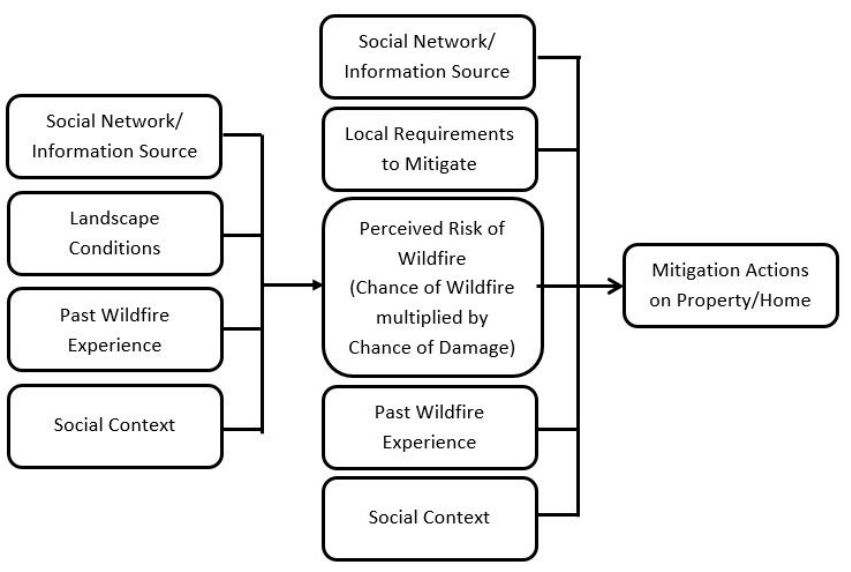

However, our empirical application extends this conceptual framework to account for the individual roles of modeled and perceived wildfire risk in terms of its two principle components: the likelihood that a wildfire could occur in the vicinity of the home site and the likelihood of damage to the home should such a wildfire occur (e.g., Ager et al. 2013). Following a multiplicative view of risk (e.g., Kasperson et al. 1988, Renn et al. 1992), we assume that homeowners' perceived wildfire risk is the product of their perceived likelihood of wildfire multiplied by their perceived likelihood of damage should a fire occur, thereby reflecting expected loss owing to wildfire. This formulation enables an analysis of factors that influence both wildfire risk perceptions and mitigation behaviors by allowing for the possibility that individual risk components are influenced by different factors. Following these hypotheses, we anticipated that future homeowner mitigation trends will show an increase in mitigation behavior in association with increased modeled risk (e.g., increased fuel loads, climate change) and increased fire behavior.

\section{METHODS}

\section{Study area}

Our study area is the eastern Cascades of central Oregon, including portions of Deschutes, Jefferson, Wasco, Klamath, and Lake counties (Fig. 2). The study area was chosen to coincide with and contribute to a CHANS modeling effort underway in the region (Spies et al. 2017). The area includes steep environmental gradients spanning cool, wet subalpine forests to high deserts covered by juniper woodlands (Spies et al. 2014). Federal lands dominate the ownership, but there is a diversity of other ownership types, including private corporate, family (e.g., nonindustrial private), and tribes. Forested residential areas have grown significantly in recent years, likely due to the area's scenic qualities, sunshine, and recreation opportunities. The fire history of the region suggests that wildfires have become more common, with wildfires often originating in wilderness landscapes and spreading to wildlandurban interface locations (Spies et al. 2014). These ecological and socioeconomic circumstances combine to present numerous challenges to landscape managers and public officials who are tasked with protecting forest resources and homes in the region.

Fig. 2. Central Oregon study area with detail near Sunriver, Oregon. (WUI = wildland-urban interface)

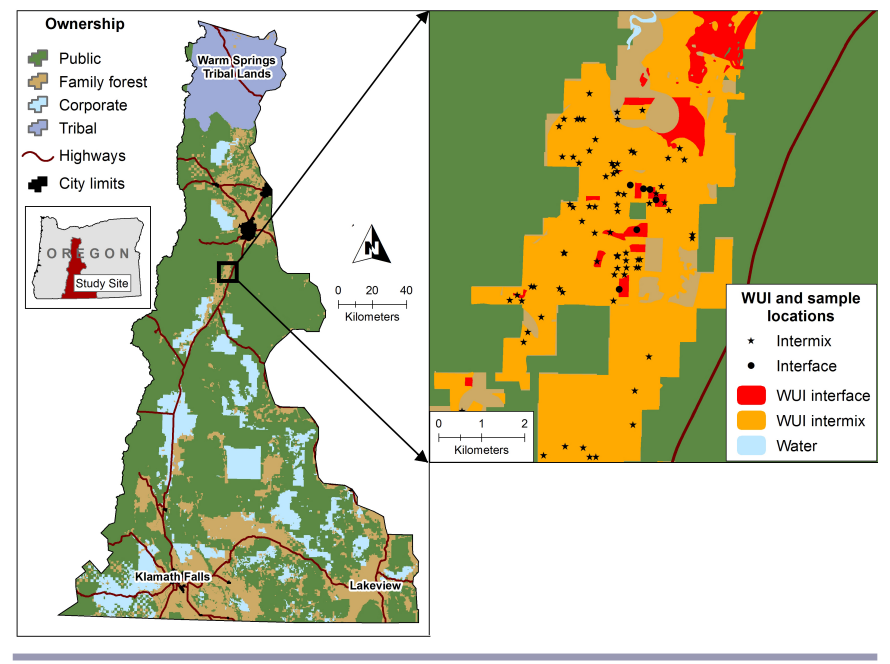

\section{Survey of homeowners}

Data describing homeowners' wildfire risk perceptions and mitigation activities were obtained using a public mail survey in Deschutes, Klamath, and Lake counties in central Oregon. Small portions of Jefferson and Wasco counties are also within the study area, but those areas are primarily within the Warm Springs Indian Reservation. No homeowners were identified in those areas. The survey focused on homeowners in wildland-urban interface and was stratified between the interface and intermix Silvis WUI 
designations (SILVIS Lab 2017). Agent-based modeling for the broader CHANS study focused on actor groups and land areas where wildfire risk was measurable and wildfire was transmittable and model-able. Our survey sample therefore excluded homes in urban areas. Also, because family forest owners were examined as a separate group by the CHANS study, we defined our target sample of WUI homeowners as those with properties of 2 ha or less. A random sample of homeowners was selected by a professional sampling company, but excluded second homes, multihome units, and vacant homes.

Surveys were successfully delivered to 1704 addresses using a modified Dillman approach, which included an introductory postcard, followed by a survey packet, a reminder postcard, and a final survey packet (Dillman et al. 2014). Mailings were made one week apart, and the survey packet included a cover letter, the questionnaire, and a business reply envelope. We received 532 responses, for a response rate of $31 \%$. This response rate is in line with recent randomly sampled survey projects on wildfire topics (e.g., Kyle et al. 2010, Brenkert-Smith et al. 2012, McNeill et al. 2013). To explore possible responder bias, we compared demographic variables from our sample to those from the three surveyed counties using U.S. Census Bureau (2015) facts. Though we cannot detect the strength or direction of the possible influence on our dependent variables with this comparison, it does provide a general sense of how our participants compared to the general local population. Our sample appeared to represent gender well, though our sample did overrepresent older individuals, those with a Bachelor's degree or higher, and those in higher income brackets (Table 2). These differences might be because this sample was drawn from properties that are single-unit dwellings, which are more likely to be inhabited by those with higher income and education levels. Hence, our concern about responder bias is minimal.

Table 2. Socioeconomic characteristics (United States Census Bureau 2015) of the survey sample compared to study area counties.

\begin{tabular}{lcccc}
\hline \hline Characteristics & $\begin{array}{c}\text { Survey } \\
\text { sample }\end{array}$ & $\begin{array}{c}\text { Deschutes } \\
\text { County }\end{array}$ & $\begin{array}{c}\text { Klamath } \\
\text { County }\end{array}$ & $\begin{array}{c}\text { Lake } \\
\text { County }\end{array}$ \\
\hline \% Female & 46.7 & 50.7 & 50.0 & 46.9 \\
\% Population 65 years or older & 41.6 & 17.4 & 18.7 & 22.7 \\
\% Bachelor's degree or higher & 47.3 & 31.0 & 19.7 & 18.6 \\
\% Median household income & 63.1 & $\$ 50,209^{\dagger}$ & $\$ 39,627^{\dagger}$ & $\$ 33,611^{\dagger}$ \\
greater than US $\$ 50,000$ & & & & \\
\hline${ }^{\dagger}$ Mean values & & & &
\end{tabular}

The survey questions asked respondents about their perceptions of wildfire risk, recent mitigation activities, experience with past wildfires, contact with individuals and groups regarding wildfire and mitigation information, and socioeconomic and demographic variables. Respondents were asked two questions of interest:

1. Considering the forests closest to your home, in your opinion, what is the chance of wildfire of any severity in the next 5 years?

2. If a wildfire were to occur in the forests closest to your home, in your opinion, what is the chance it would damage your property or home?
For both questions, respondents were asked to record their answers using a percentage scale ranging from 0 to $100 \%$. The responses to these questions were used to develop two response variables: CHANCE OF WILDFIRE and CHANCE OF DAMAGE.

Another set of 12 questions asked respondents about any mitigation actions they have taken. We asked this in two ways. One question asked respondents to indicate "yes" or "no" whether they had taken any of several "Firewise" activities within the last 5 years to protect their property and home from wildfire, including "planting fire-resistant plants, using non-flammable building materials, pruning tree branches within 85 feet $(25.9 \mathrm{~m})$ of the home, reducing the density of trees within 100 feet $(30.5 \mathrm{~m})$ of the residence, as well as other activities" to reduce fire risk near a home. This variable is the primary mitigation variable used in the body of this manuscript. A following set of 11 questions asked respondents to indicate "yes" or "no" whether they had participated in specific mitigation activities listed individually, including general planning activities (e.g., preparing a home evacuation plan), community activities (e.g., attending community-based meetings related to wildfires), property protection activities (e.g., reducing tree density within 100 feet [30.5 m] of your home), and home protection activities (e.g., stacking firewood at least 30 feet [ $9 \mathrm{~m}]$ from the home). Our focus is on property and home mitigation, so we examined only the seven variables in those categories. Additional data describing biophysical conditions in the vicinity of sampled homeowners were developed by geo-locating survey respondents' addresses on GIS layers that described tree density estimations (TREES PER HECTARE) from the Gradient Nearest Neighbor (GNN) Forest Structure Model (Ohmann and Gregory 2002), and output from a wildfire model that described burn probabilities and intensities (Ager et al. 2013) (see Appendix 1).

\section{Empirical model}

There are challenges with modeling homeowner wildfire risk mitigation behavior, including reliance on self-reporting to assess compliance. Each mitigation activity is a categorical variable, usually with a "yes" or "no" response. Creating an overall mitigation measure is then done in several ways. There are four general approaches that researchers have employed to measure homeowner wildfire risk mitigation activity using regression models (Table 1): dummy, number, individual, and group. The dummy method uses a dummy variable that indicates whether a survey respondent has taken any one of several mitigation actions. Although straightforward, this approach treats all mitigation actions equally (e.g., cleaning gutters is equal to installing a metal roof). Another approach is to estimate mitigation as a number of individual mitigation actions a given survey respondent has taken, such that a respondent who has taken two actions (e.g., cleaning gutters and planting fire-resistant vegetation) is treated as having exerted twice as much mitigation effort as a respondent who has taken a single action (e.g., installing a metal roof). An advantage of this number approach is that it arguably provides a finer metric of increasing mitigation effort than a simple dummy variable. However, such an interpretation necessarily assumes that homeowners all face equal opportunities regarding mitigation. For example, if the number is based on whether survey respondents cleaned gutters, planted fire-resistant vegetation, or installed a metal roof, whether or not a respondent could earn a 
number of " 3 " would depend in part on whether they even had any gutters to clean, a desire to plant any vegetation, and a nonmetal roof that they could replace. Some homeowners may own homes that lack gutters, some may desire little in the way of landscaping, and some may have purchased their homes with a metal roof already installed. The individual method estimates behavior for each of several activities individually (i.e., a separate regression model is built for each specific mitigation action). A shortcoming is that findings reflect factors that influence individual actions and not mitigation behavior more generally. The group method lumps individual actions into similar groupings and then uses either a yes/no response, number of actions, or means of activities within the groups to examine mitigation behavior. Depending on how those measures occur within the groups, this approach could treat all actions equally and/or assume all homeowners have equal opportunities. No method is clearly superior or capable of discerning some of the fine details of mitigating. For our work, the choice of method was guided by the CHANS model requirements, though we also chose to employ two methods in order to broaden our ability to address several of the limitations listed previously in this paragraph. Our primary method was to examine mitigation as a dummy variable, though we also tested an alternative model that examined mitigation as the number of activities conducted, to further explore and confirm our findings.

In the broader agent-based modeling research context of this study, our analysis was intended to serve in developing a predictive equation for describing the likelihood that homeowners would conduct any wildfire risk mitigation activities to the home site. In this case, neither the agent-based model (Envision) (Spies et al. 2017) nor the wildfire simulation models integrated into Envision could distinguish between different mitigation actions homeowners might take. Rather, these models viewed mitigation effort by homeowners as an "all or nothing" discrete variable. For this reason, we elected to examine survey respondents' mitigation efforts by using a simple dummy variable approach. However, in Appendix 2, we provide estimation results of an alternative regression model using a count approach.

Our empirical model tested the influence of factors hypothesized to influence homeowners' wildfire risk perceptions and their likelihood of conducting mitigation activities. Following and expanding on the general structure developed by Champ et al. (2013), we assumed that homeowners' perceptions of both the likelihood of wildfire (CHANCE OF WILDFIRE*) and the likelihood of damage (CHANCE OF DAMAGE ${ }^{*}$ ) can be described by sets of explanatory variables $\mathrm{x}_{1}$ and $\mathrm{x}_{2}$, respectively, as:

$$
\begin{aligned}
& \text { CHANCE OF WILDFIRE } * \alpha_{1} \mathrm{x}_{1}+\varepsilon_{1} \\
& \text { CHANCE OF DAMAGE }^{*}=\alpha_{2} \mathrm{x}_{2}+\varepsilon_{2}
\end{aligned}
$$

where $\alpha_{1}$ and $\alpha_{2}$ are vectors of unstandardized estimated coefficients, and $\varepsilon_{1}$ and $\varepsilon_{2}$ are error. We assumed that the likelihood of wildfire and the likelihood of damage constitute the two principle components of wildfire risk (Brenkert-Smith et al. 2006), such that PERCEIVED RISK ${ }^{*}$ can be defined as:

$$
\mathrm{PR}^{*}=\mathrm{LW}^{*} \times \mathrm{LD}^{*}
$$

Lastly, we assumed homeowners' wildfire risk mitigation activities MITIGATION $^{*}$ can be described by their perceived risk $\beta$ PERCEIVED RISK ${ }^{*}$ and other explanatory variables $\mathrm{x}_{3}$ as:

$$
\text { MITIGATION } *=\alpha_{3} x_{3}+\beta \text { PERCEIVED RISK } * \varepsilon_{2}
$$

where the vector $\alpha_{3}$ and $\beta$ are unstandardized estimated coefficients and $\varepsilon_{3}$ is error. The model structure accounts for potential joint determination of perceived wildfire risk and mitigation behavior suggested by Champ et al. (2013), while enabling examination of factors that influence the individual components of perceived wildfire risk.

We assumed that survey respondents' wildfire risk perceptions are reflected in the dependent variables CHANCE OF WILDFIRE and CHANCE OF DAMAGE, and we used them in a set of regression equations to represent the structural model terms CHANCE OF WILDFIRE* ${ }^{*}$ and CHANCE OF DAMAGE*. Because the likelihood variables CHANCE OF WILDFIRE and CHANCE OF DAMAGE are both confined to values between 0 and $100 \%$, we applied a logit transformation to each variable as:

Logit(CHANCE OF WILDFIRE $_{\mathrm{i}}$

$$
=\ln \left[\frac{\text { CHANCE OF WILDFIRE }_{\mathrm{i}}}{1-\text { CHANCE OF WILDFIRE }_{\mathrm{i}}}\right]
$$

and

$$
\begin{aligned}
& \operatorname{Logit}_{\left(C_{\text {CHANCE OF DAMAGE }} \text { ) }_{\mathrm{i}}\right.} \\
& \qquad=\ln \left[\frac{\text { CHANCE OF DAMAGE }_{\mathrm{i}}}{1-\text { CHANCE OF DAMAGE }_{\mathrm{i}}}\right]
\end{aligned}
$$

where $\ln$ is the natural logarithm. We used this empirical structure to estimate ordinary least squares regression equations that described survey respondents' perceptions of the likelihood of wildfire burning near their home within the next 5 years (CHANCE OF WILDFIRE) and the likelihood that such a wildfire would damage their property or home (CHANCE OF DAMAGE) as functions of biophysical and socioeconomic factors.

To examine mitigation behavior, we constructed the dependent variable MITIGATION as a binary that represented whether each respondent answered "yes" or "no" to completing Firewise activities over the previous 5 years, with 0 indicating no activity and 1 indicating activity. Assuming that the error term is logistically distributed implies a binomial logit model:

$$
\operatorname{Prob}(\text { MITIGATION }=1)=\left[\frac{\mathrm{e}^{\alpha_{3} \mathrm{x}_{3}+\beta \text { PERCEIVED RISK }}{ }^{*}}{1+\mathrm{e}^{\alpha_{3} \mathrm{x}_{3}+\beta \text { PERCEIVED RISK }}}\right]
$$

where $\mathrm{e}$ is the base of the natural logarithm (Greene 2012:688).

To account for the influence of respondents' wildfire risk perceptions on their risk mitigation actions, we computed the variable PERCEIVED RISK as the product of CHANCE OF WILDFIRE and CHANCE OF DAMAGE and used it as an explanatory variable in the mitigation estimated equations. We estimated two different logit models that described survey respondents' mitigation activities (MITIGATION). One version was based on PERCEIVED RISK variable values computed from the survey respondent-reported values for the expected loss variables CHANCE OF WILDFIRE and CHANCE OF 
Table 3. Descriptions of dependent and independent variables examined in the empirical models $(N=284)$.

\begin{tabular}{|c|c|c|c|c|}
\hline Variables drawn from the survey & Definition & Minimum & Mean & Maximum \\
\hline CHANCE OF WILDFIRE & $\begin{array}{l}\text { Respondents' self-reported perception of the chance a wildfire will burn } \\
\text { near their home in the next } 5 \text { years }\end{array}$ & 0.000 & 0.678 & 1.000 \\
\hline CHANCE OF DAMAGE & $\begin{array}{l}\text { Respondents' self-reported perception of the chance a wildfire, if it } \\
\text { occurs, will damage their property or home within the next } 5 \text { years }\end{array}$ & 0.000 & 0.314 & 1.000 \\
\hline PERCEIVED RISK & $\begin{array}{l}\text { Variable equal to respondents' self-reported "chance of wildfire" } \times \\
\text { "chance of damage" }\end{array}$ & 0.000 & 0.230 & 1.000 \\
\hline MITIGATION & $\begin{array}{l}\text { 1: Respondent reported mitigation activity within the past } 5 \text { years; } 0 \text { : } \\
\text { otherwise }\end{array}$ & 0.000 & 0.768 & 1.000 \\
\hline WILDFIRE WITHIN MILES & $\begin{array}{l}\text { 1: Respondent reported experiencing wildfire within several miles of } \\
\text { their parcel within the past } 5 \text { years; } 0 \text { : otherwise }\end{array}$ & 0.000 & 0.718 & 1.000 \\
\hline $\begin{array}{l}\text { WILDFIRE WITHIN } \\
\text { NEIGHBORHOOD }\end{array}$ & $\begin{array}{l}\text { 1: Respondent reported experiencing wildfire within their neighborhood } \\
\text { within the past } 5 \text { years; } 0 \text { : otherwise }\end{array}$ & 0.000 & 0.158 & 1.000 \\
\hline $\begin{array}{l}\text { PRESCRIBED BURN WITHIN } \\
\text { MILES }\end{array}$ & $\begin{array}{l}\text { 1: Respondent reported experiencing prescribed fire within several miles } \\
\text { of their parcel within the past } 5 \text { years; } 0 \text { : otherwise }\end{array}$ & 0.000 & 0.718 & 1.000 \\
\hline $\begin{array}{l}\text { PRESCRIBED BURN NEAR } \\
\text { NEIGHBORHOOD }\end{array}$ & $\begin{array}{l}\text { 1: Respondent reported experiencing prescribed fire just outside their } \\
\text { neighborhood within the past } 5 \text { years; } 0 \text { : otherwise }\end{array}$ & 0.000 & 0.264 & 1.000 \\
\hline $\begin{array}{l}\text { ADVICE: FAMILY OR } \\
\text { NEIGHBOR }\end{array}$ & $\begin{array}{l}\text { 1: Respondent reported advice from family or neighbors about } \\
\text { addressing wildfire; } 0 \text { : otherwise }\end{array}$ & 0.000 & 0.430 & 1.000 \\
\hline $\begin{array}{l}\text { ADVICE: LOCAL } \\
\text { GOVERNMENT }\end{array}$ & $\begin{array}{l}\text { 1: Respondent reported advice from city or county government or fire } \\
\text { department about addressing wildfire; } 0 \text { : otherwise }\end{array}$ & 0.000 & 0.518 & 1.000 \\
\hline $\begin{array}{l}\text { ADVICE: LOCAL FIRE } \\
\text { AWARENESS GROUP }\end{array}$ & $\begin{array}{l}\text { 1: Respondent reported advice from local fire awareness group about } \\
\text { addressing wildfire; } 0 \text { : otherwise }\end{array}$ & 0.000 & 0.285 & 1.000 \\
\hline PROPERTY OWNER & 1: Respondent reported that they owned the property; 0 : rented & 0.000 & 0.915 & 1.000 \\
\hline YEARS AT PROPERTY & Number of years respondent reported living at residence & 0.750 & 13.099 & 60.000 \\
\hline AGE & Respondents' self-reported age & 24.000 & 58.091 & 86.000 \\
\hline COLLEGE-EDUCATED & $\begin{array}{l}\text { 1: Respondent reported that they possessed a college degree; } 0 \text { : } \\
\text { otherwise }\end{array}$ & 0.000 & 0.511 & 1.000 \\
\hline $\begin{array}{l}\text { HOMEOWNERS } \\
\text { ASSOCIATION RULES }\end{array}$ & $\begin{array}{l}\text { 1: Respondent reported that their homeowners association or } \\
\text { subdivision has landscaping and building rules to protect against fire; } 0 \text { : } \\
\text { otherwise }\end{array}$ & 0.000 & 0.317 & 1.000 \\
\hline $\begin{array}{l}\text { Variables drawn from wildfire or } \\
\text { landscape models }\end{array}$ & Definition & Minimum & Mean & Maximum \\
\hline BURN PROBABILITY & $\begin{array}{l}\text { Annual likelihood (\%) of burning given a random ignition in the study } \\
\text { area (Ager et al. 2013), averaged within a 1-km radius of the parcel } \\
\text { center }\end{array}$ & 0.000 & 0.257 & 1.070 \\
\hline $\begin{array}{l}\text { CONDITIONAL FLAME } \\
\text { LENGTH }\end{array}$ & $\begin{array}{l}\text { Average flame length }(\mathrm{m}) \text { if a fire occurs (Ager et al. 2013), averaged } \\
\text { within a } 1-\mathrm{km} \text { radius of the parcel center }\end{array}$ & 0.001 & 2.566 & 9.642 \\
\hline TREES PER HECTARE & Number of trees per hectare within a $1-\mathrm{km}$ radius & 0.000 & 150.46 & 1069.74 \\
\hline
\end{tabular}

DAMAGE. The second version was based on the values of CHANCE OF WILDFIRE and CHANCE OF DAMAGE predicted using the estimated coefficients reported in Table 5. This second version controlled for potential simultaneity in the relationship between survey respondents' perceptions of the likelihood of wildfire and damage and their propensity to conduct mitigation activities, and it distinguishes between the effects each explanatory variable may have on these.

\section{Explanatory variables}

Survey and other data were used to develop explanatory variables that were hypothesized to influence homeowners' perceptions of the chance of wildfire near their property, the chance of damage to their home, and their likelihood to have conducted any mitigation activities (Table 3 ). We expected that respondents' past experiences with wildfire near their homes (WILDFIRE WITHIN MILES, WILDFIRE WITHIN NEIGHBORHOOD) would be positively correlated with both respondents' perceptions of the chance of wildfire and chance of damage to their homes in the event of wildfire, as well as their propensity to conduct mitigation activities. We also expected that respondents' past experiences with prescribed burning near their homes (PRESCRIBED BURN WITHIN MILES, PRESCRIBED BURN NEAR NEIGHBORHOOD) would be correlated with their perceptions of the chance of wildfire and damage. However, our expectation of the potential direction of this influence was ambiguous. On the one hand, by reducing forest fuel, evidence of prescribed burning could lead some respondents to perceive lower chances of wildfire and damage relative to respondents who did not report prescribed burning near their homes, which suggested a negative relationship. On the other hand, the very fact that prescribed burning is deemed necessary by public officials to reduce wildfire hazard could lead other respondents to perceive higher chances of wildfire and damage relative to respondents who did not report prescribed burning near their homes, which suggested a positive relationship.

We developed additional biophysical variables to approximate survey respondents' exposure to wildfire risk (Table 3). The variables BURN PROBABILITY and CONDITIONAL 
FLAME LENGTH describe the wildfire likelihood and potential intensity within a $1-\mathrm{km}$ radius of each respondent's home. These two variables were developed using the wildfire simulation model FSIM and methods described by Finney et al. (2011), which generates wildfire scenarios for a large number of hypothetical wildfire seasons and incorporates fire and weather history data. Fuel loads for these wildfire simulations were obtained using the national LANDFIRE data grid (Rollins 2009). For additional description of how BURN PROBABILITY and CONDITIONAL FLAME LENGTH were developed, see Appendix 1. TREES PER HECTARE, which was derived from the GNN Forest Structure Model (Ohmann and Gregory 2002), describes the average tree density within a $1-\mathrm{km}$ radius of each survey respondent's home, as a proxy measure of the presence of forest fuel that homeowners may perceive. Following with previous risk perception research (e.g., Brenkert-Smith et al. 2006, McCaffrey 2008, Martin et al. 2009), we expected that these variables might have a positive influence on respondents' wildfire risk perceptions and mitigation likelihood, suggesting that respondents are making risk assessments in line with experts' assessments (reflected in the model output).

We also sought to test the influence of respondents' contacts with various individuals, agencies, and organizations from which respondents may receive advice concerning their exposure to wildfire risk and approaches to mitigating risk. We tested these potential influences using the explanatory variables ADVICE: FAMILY OR NEIGHBOR, ADVICE: LOCAL GOVERNMENT, and ADVICE: LOCAL FIRE AWARENESS GROUP. We would expect these explanatory variables to have positive and statistically significant estimated coefficients if such contacts are positively correlated with wildfire risk perceptions and mitigation activities. Lastly, we tested the influence of several additional characteristics of respondents, including whether respondents reported owning the properties on which they lived (PROPERTY OWNER), the number of years they reported living at their current residence (YEARS AT PROPERTY), their age (AGE), and their level of education (COLLEGE-EDUCATED). The explanatory variable HOMEOWNERS ASSOCIATION RULES (HOA RULES) identified respondents who were subject to homeowners association or subdivision rules concerning landscaping and building to protect against wildfire, and would be expected to be positively correlated with respondents' propensity to conduct mitigation activities.

\section{Visualizing and predicting homeowner mitigation activity}

We used the coefficients from the three estimated equations (CHANCE OF WILDFIRE, CHANCE OF DAMAGE, and MITIGATION) to develop a set of predictive equations to parameterize an agent-based model, Envision (Bolte et al. 2007), as part of a CHANS study examining the management of wildfire risk in the fire-prone landscape of central Oregon (Spies et al. 2014, Spies et al. 2017). Envision was designed to provide spatially explicit landscape change simulations that are likely to result from hypothetical management scenarios. Our predictive equations provided predictions within Envision about whether homeowners in any given management scenario were likely to conduct wildfire risk mitigation activities given biophysical conditions present in simulated scenarios. The resulting predictions were a key determinant in identifying how many homes were likely to suffer damage under each simulated management scenario.
The predictive equations used biophysical variable values resulting from Envision landscape simulations as input values for the biophysical explanatory variables: BURN PROBABILITY, CONDITIONAL FLAME LENGTH, TREES PER HECTARE, WILDFIRE WITHIN MILES, WILDFIRE WITHIN NEIGHBORHOOD, PRESCRIBED BURN WITHIN MILES, and PRESCRIBED BURN NEAR NEIGHBORHOOD. All other explanatory variables, which were not simulated by Envision, were set at their sample mean values. We examined the sensitivity of predicted values that resulted from the predictive equations by comparing homeowner mitigation activity likelihoods for three cases: (1) setting all biophysical explanatory values at their minimum sample values, (2) setting all biophysical explanatory values at their maximum sample values, and (3) setting all biophysical explanatory values at their mean sample values. Additionally, we visually examined the spatial patterns of predicted values relative to key biophysical variables (e.g., past occurrence of wildfire) by mapping them in ArcGIS at a resolution of $30 \mathrm{~m}$.

\section{RESULTS}

\section{Characteristics of the survey sample}

Our data included responses from 284 homeowners who had completed the survey questionnaire sufficiently to populate the dependent and explanatory variables of interest in our analysis. Responses reflected significant awareness and concern about the degree of wildfire hazard in this fire-prone dry forest landscape (Tables 3 and 4). On average, survey respondents believed that there is a $68 \%$ likelihood that a wildfire will burn near their home in the next 5 years, and suggested $31 \%$ as the likelihood that such a wildfire, if it occurs, will damage their property. If we combine these likelihoods to compute an average expected loss, on average survey respondents believe there is a $21 \%(0.68 \times 0.31)$ likelihood that a wildfire will damage their home within the next 5 years. This contrasts with an estimated sample average annual burn probability of $0.3 \%$ based on fire behavior models. In other words, homeowners' risk perceptions, on average, appear to be orders of magnitude higher than risk assessments based on wildfire model output. The high perception of risk about wildfire is reflected in a fairly high propensity among respondents for conducting mitigation activities to reduce wildfire risk, with $77 \%$ reporting activity in the past 5 years.

Table 4. Reported mitigation behavior.

\begin{tabular}{|c|c|}
\hline Mitigation & $\begin{array}{c}\% \\
\text { conducted }\end{array}$ \\
\hline \multicolumn{2}{|l|}{ Property protection activities: } \\
\hline Plant fire-resistant plants & 37 \\
\hline Plant trees and shrubs at least 15 feet $(4.6 \mathrm{~m})$ apart & 39 \\
\hline $\begin{array}{l}\text { Prune the branches of trees within } 85 \text { feet }(25.9 \mathrm{~m}) \text { of your } \\
\text { home }\end{array}$ & 67 \\
\hline $\begin{array}{l}\text { Reduce the density of trees within } 100 \text { feet }(30.5 \mathrm{~m}) \text { of your } \\
\text { home }\end{array}$ & 51 \\
\hline \multicolumn{2}{|l|}{ Home protection activities: } \\
\hline $\begin{array}{l}\text { Clean roof surfaces/gutters and surrounding vegetation to } \\
\text { avoid accumulation of needles, leaves, and dead plants }\end{array}$ & 86 \\
\hline Stack firewood/lumber at least 30 feet $(9.1 \mathrm{~m})$ from the home & 58 \\
\hline $\begin{array}{l}\text { Use nonflammable building materials such as tile, slate, } \\
\text { stone, etc. }\end{array}$ & 55 \\
\hline
\end{tabular}


Survey respondents also appear to be fairly familiar with wildfire; most reported experiencing a wildfire and/or prescribed fire nearby in the past 5 years. Survey respondents reported obtaining information about addressing wildfire from a variety of sources, including family and neighbors (43\%), local government agencies $(52 \%)$, and local fire awareness groups (28\%). Most survey respondents $(92 \%)$ owned the homes for which they were responding, and were long-term residents in that home and in central Oregon (13 and 21 years, respectively). One-third reported that their homeowners association or subdivision has landscaping and building rules to protect against wildfire.

\section{Risk perception model estimation results}

The estimated equation for CHANCE OF WILDFIRE was statistically significant $(F=5.32$, df $=8, P<0.0001)$ and had an adjusted $R^{2}$ of 0.109 (Table 5). Respondents' self-reported perceptions of the chance of wildfire were positively and weakly correlated $(P<0.10)$ with the estimated average annual likelihood of wildfire (BURN PROBABILITY) within a $1-\mathrm{km}$ radius of respondents' homes. Respondents' perceptions of the chance of wildfire also were positively correlated with respondents' past exposure to wildfire and prescribed burning. The presence of prescribed burning in the vicinity of the homeowner's property tended to heighten respondents' concerns about wildfire and resulting damage to their homes. None of the estimated coefficients for ADVICE: FAMILY OR NEIGHBOR, ADVICE: LOCAL GOVERNMENT, or ADVICE: LOCAL FIRE AWARENESS GROUP variables were statistically significant, which suggested that respondents' perceptions of the chance of wildfire were not strongly correlated with their self-reported contact with those individuals, agencies, or groups. Respondents who possessed a college degree had lower expectations for chance of wildfire.

The estimated equation for CHANCE OF DAMAGE also was statistically significant $(F=11.332, \mathrm{df}=7, P<0.0001)$ and had an adjusted $\mathrm{R}^{2}$ of 0.204 (Table 5). Respondents' self-reported perceptions of the chance of damage to their homes, should a wildfire occur, were positively correlated $(P<0.05)$ with the estimated average flame length (CONDITIONAL FLAME LENGTH) within a $1-\mathrm{km}$ radius of respondents' homes. Respondents' perceptions of the chance of damage also were positively correlated with average tree density in the vicinity of their home sites, with respondents' past exposure to wildfire and prescribed burning, and with their self-reported contact with local fire awareness groups (but not with the other advice variables).

\section{Mitigation activities likelihood model estimation results}

The estimated equations for likelihood of mitigation activitiesone based on survey respondent-reported PERCEIVED RISK and one based on the predicted values for the CHANCE OF WILDFIRE and CHANCE OF DAMAGE-were both statistically significant (Table 6). Both equations indicate that respondents' perceptions of the chance of wildfire and chance of damage, combined, were positively correlated with their propensity to conduct mitigation activities. Respondents who reported experiencing past exposure to wildfire had greater propensity to conduct mitigation activities. Our results indicated that respondents' propensity to conduct mitigation activities was positively correlated with self-reported contact with local government agencies and local fire awareness groups but not with advice from family and neighbors. Respondents appeared more likely to mitigate with increased residence time and existence of HOA landscaping and building rules to protect against fire. Older respondents were less likely to conduct mitigation.

Lastly, we estimated alternative logit models that included the variables BURN PROBABILITY and CONDITIONAL FLAME LENGTH to test whether these proxies for biophysical risk were directly correlated with mitigation likelihood in addition to their indirect correlation through the PERCEIVED RISK variable (Appendix 2, Table A2-1). However, estimated coefficients for both variables were found to be statistically insignificant $(P>0.25)$, which indicated that their influence likely exists primarily through respondents' perceived risk, consistent with the conceptual framework outlined by Fischer et al. (2014). Additionally, results of an alternative ordered model of the number of mitigation activities (Appendix 2, Table A2-2) yielded similar results to those we found with the binary MITIGATION variable. An alternative ordered model that included BURN PROBABILITY and CONDITIONAL FLAME LENGTH again yielded estimated coefficients for those variables that were not statistically significant $(P>0.25)$. Our results suggest that the influence of biophysical variables that characterize fuel conditions (i.e., fire hazard) on respondents' mitigation behavior likely occurs indirectly through respondents' perceptions of fire hazard on their forest parcels.

\section{Sensitivity analysis for homeowner mitigation model}

The resulting homeowner mitigation model used in Envision projected the likelihood of any mitigation action being taken by a given homeowner:

$$
\operatorname{Pr}(\text { MITIGATION })=\frac{\mathrm{e}^{\mathrm{x}}}{1+\mathrm{e}^{\mathrm{x}}}
$$

where:

$$
\begin{aligned}
\mathrm{x}=1.106+(1.687 & \times \text { WILDFIRE WITHIN NEIGHBORHOOD }) \\
& +(2.154 \times \text { CHANCE OF WILDFIRE } \\
& \times \text { CHANCE OF DAMAGE })
\end{aligned}
$$

and:

$$
\begin{aligned}
& \text { CHANCE OF WILDFIRE }=\frac{\mathrm{e}^{\mathrm{y}}}{1+\mathrm{e}^{\mathrm{y}}} \\
& \text { CHANCE OF DAMAGE }=\frac{\mathrm{e}^{\mathrm{z}}}{1+\mathrm{e}^{\mathrm{z}}}
\end{aligned}
$$

where:

$$
\begin{aligned}
\mathrm{y}=0.735 & +(209.235 \times \text { BURN PROBABILITY }) \\
& +(1.747 \times \text { WILDFIRE WITHIN MILES }) \\
& +(1.322 \times \text { PRESCRIBED BURN WITHIN MILES })
\end{aligned}
$$

$$
\begin{array}{rl}
\mathrm{z}=-5 & 556+(0.390+\text { CONDITIONAL FLAME LENGTH }) \\
& +(0.006 \times \text { TREES PER HECTARE }) \\
& +(1.775 \times \text { WILDFIRE WITHIN MILES }) \\
& +(1.775 \times \text { PRECRIBED BURN NEAR NEIGHBORHOOD })
\end{array}
$$

Sensitivity analysis indicated that CHANCE OF WILDFIRE was relatively insensitive to variation in individual biophysical explanatory variables, but CHANCE OF DAMAGE was quite sensitive, especially to CONDITIONAL FLAME LENGTH and TREES PER HECTARE-more so than for any other explanatory variable we examined (Table 7). MITIGATION was relatively insensitive to variation in the BURN PROBABILITY variable but was somewhat more sensitive to the 
Table 5. Estimated coefficients of logistic regression models describing survey respondents' self-reported perceptions of likelihood of wildfire and property damage $(N=284)$.

\begin{tabular}{|c|c|c|c|c|c|c|}
\hline \multirow[b]{2}{*}{ Explanatory variables } & \multicolumn{3}{|c|}{ CHANCE OF WILDFIRE } & \multicolumn{3}{|c|}{ CHANCE OF DAMAGE } \\
\hline & $\begin{array}{l}\text { Estimated } \\
\text { coefficient }\end{array}$ & $t$ statistic & Odds ratio & Estimated coefficient & $t$ statistic & Odds ratio \\
\hline Constant & $1.704 \dagger$ & 1.70 & - & $-6.401 \S$ & -9.15 & - \\
\hline BURN PROBABILITY & $2.092 \dagger$ & 1.75 & 8.101 & - & - & - \\
\hline $\begin{array}{l}\text { CONDITIONAL FLAME } \\
\text { LENGTH }\end{array}$ & - & - & - & $0.390 \%$ & 2.13 & 1.477 \\
\hline TREES PER HECTARE & - & - & - & $0.006 \S$ & 4.83 & 1.006 \\
\hline WILDFIRE WITHIN MILES & $1.747 \S$ & 3.19 & 5.737 & $1.775 \S$ & 3.33 & 5.900 \\
\hline $\begin{array}{l}\text { PRESCRIBED BURN } \\
\text { WITHIN MILES }\end{array}$ & $1.322 \ddagger$ & 2.42 & 3.751 & - & - & - \\
\hline $\begin{array}{l}\text { PRESCRIBED BURN NEAR } \\
\text { NEIGHBORHOOD }\end{array}$ & - & - & - & 0.929 & 1.63 & 2.532 \\
\hline $\begin{array}{l}\text { ADVICE: FAMILY OR } \\
\text { NEIGHBOR }\end{array}$ & -0.657 & -1.39 & 0.518 & 0.196 & 0.40 & 1.217 \\
\hline $\begin{array}{l}\text { ADVICE: LOCAL } \\
\text { GOVERNMENT }\end{array}$ & 0.176 & 0.37 & 1.192 & 0.797 & 1.61 & 2.219 \\
\hline $\begin{array}{l}\text { ADVICE: LOCAL FIRE } \\
\text { AWARENESS GROUP }\end{array}$ & 0.085 & 0.16 & 1.089 & $1.221 \S$ & 2.20 & 3.391 \\
\hline PROPERTY OWNER & -1.202 & -1.43 & 0.301 & - & - & - \\
\hline $\begin{array}{l}\text { COLLEGE-EDUCATED } \\
\text { Summary statistics: }\end{array}$ & $-1.570 \S$ & $\begin{array}{c}-3.44 \\
\text { usted } R^{2}= \\
\mathrm{df}=8, P\end{array}$ & 0.208 & $F=11$ & $\begin{array}{c}-\overline{R^{2}}=0 \\
\text { df }=7, P\end{array}$ & - \\
\hline
\end{tabular}

Note: Estimated using ordinary least squares regression with dependent variables computed as logit transformations of respondents' self-reported chance of wildfire and chance of damage.

$\dagger, \ddagger$, and $\S$ indicate statistical significance at $10 \%, 5 \%$, and $1 \%$ levels, respectively.

CONDITIONAL FLAME LENGTH variable. The explanatory variable WILDFIRE WITHIN NEIGHBORHOOD yielded the greatest range of variation (79-95\%) in mitigation likelihood. All in all, the sensitivity analysis suggested that homeowners' wildfire risk perceptions vary, and that the influence of biophysical factors was strongest via the risk component of chance of damage to the home, and was represented in our analysis by the CONDITIONAL FLAME LENGTH and TREES PER HECTARE variables. When all biophysical explanatory variables were considered, the predicted percent of respondents who would take mitigation action varied from a minimum of $75 \%$ to a maximum of $99 \%$ (Table 7 ).

\section{Visualizing and predicting homeowner mitigation behavior on the landscape}

Using ArcGIS, initial predictions of mitigation likelihood were computed for a small portion of the landscape at 30-m resolution based on current biophysical conditions in order to visualize biophysical and mitigation behavior gradients across these small ownerships (Fig. 3). The resulting map highlights the positive influence of trees per hectare and higher potential flame lengths on the likelihood that WUI homeowners completed mitigation activities; past wildfires had more moderate influence.

Using Envision, we ran simulations of the northern section of the study area to investigate possible changes in WUI homeowner mitigation behavior based on future changes in biophysical conditions under three management scenarios: status quo, no management on federal lands, and a management regime focused on restoration. Aggregate results from Envision indicated a gradual increase in the likelihood of completing mitigation activities under all three scenarios but no obvious differences in mitigation rates across the three scenarios (Fig. 4). ArcGIS visualization using the Envision output data for year 50 (Fig. 5) indicated that this increase in mitigation likelihood likely is a result of projected increases in trees per hectare and potential flame length under the simulated management scenarios.

Fig. 3. Initial (year zero) biophysical and mitigation behavior variable variation around Sunriver, Oregon. $(\mathrm{WUI}=$ wildlandurban interface)

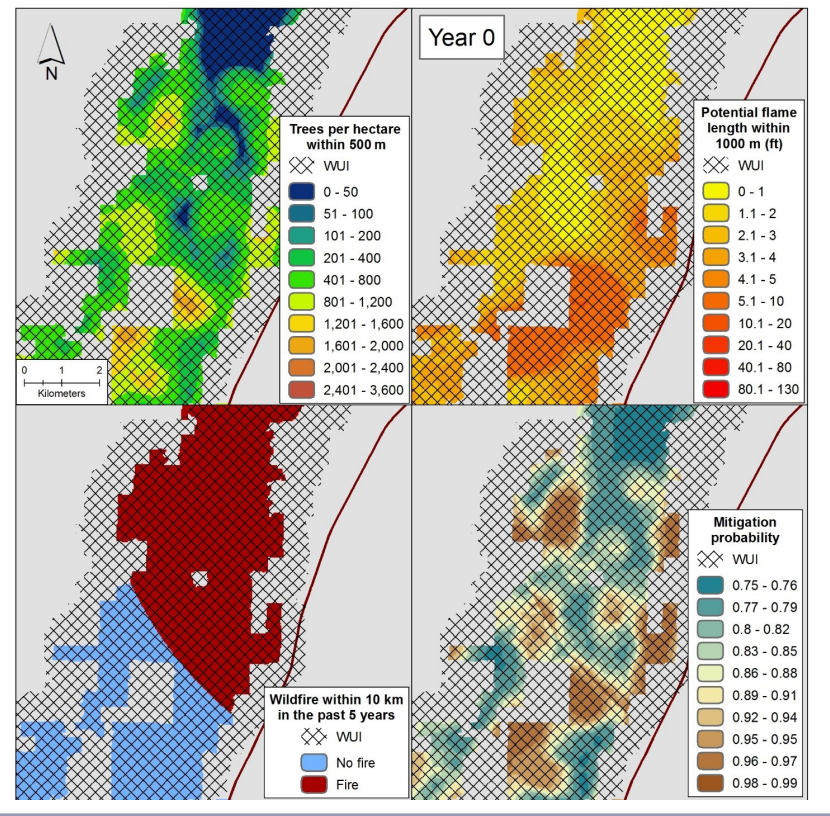


Table 6. Estimated coefficients of logit models describing survey respondents self-reported likelihood of conducting mitigation activities within the past 5 years $(N=284)$.

\begin{tabular}{|c|c|c|c|c|c|c|}
\hline \multirow[b]{2}{*}{ Explanatory variables } & \multicolumn{3}{|c|}{$\begin{array}{l}\text { With respondent-reported value of PERCEIVED } \\
\text { RISK variable } \dagger\end{array}$} & \multicolumn{3}{|c|}{ With predicted value of PERCEIVED RISK variable } \\
\hline & $\begin{array}{l}\text { Estimated } \\
\text { coefficient }\end{array}$ & $\begin{array}{l}\text { Wald Chi- } \\
\text { square }\end{array}$ & Odds ratio & $\begin{array}{l}\text { Estimated } \\
\text { coefficient }\end{array}$ & $\begin{array}{l}\text { Wald Chi- } \\
\text { square }\end{array}$ & Odds ratio \\
\hline Constant & -0.370 & 0.50 & - & -0.401 & 0.54 & - \\
\hline PERCEIVED RISK $\dagger$ & $1.272 \S$ & 1.71 & 3.566 & - & - & - \\
\hline PERCEIVED RISK + & - & - & - & $2.154 \S$ & 1.84 & 8.615 \\
\hline WILDFIRE IN NEIGHBORHOOD & $1.571 \mid$ & 2.36 & 4.811 & 1.687 & 2.56 & 5.405 \\
\hline ADVICE: FAMILY OR NEIGHBOR & 0.328 & 0.97 & 1.389 & 0.337 & 0.99 & 1.400 \\
\hline ADVICE: LOCAL GOVERNMENT & 0.9329 & 2.72 & 2.538 & 0.812 & 2.33 & 2.253 \\
\hline ADVICE: LOCAL FIRE & $1.806^{\top}$ & 2.87 & 6.087 & 1.625 & 2.53 & 5.080 \\
\hline \multicolumn{7}{|l|}{ AWARENESS GROUP } \\
\hline PROPERTY OWNER & 1.373 & 2.41 & 3.946 & $1.247 \mid$ & 2.22 & 3.479 \\
\hline TENURE & $0.031 \S$ & 1.82 & 1.031 & $0.031 \S$ & 1.83 & 1.031 \\
\hline AGE & $-0.027 \mid$ & 2.08 & 0.973 & $-0.024 \S$ & 1.82 & 0.977 \\
\hline $\begin{array}{l}\text { HOMEOWNERS ASSOCIATION } \\
\text { RULES }\end{array}$ & 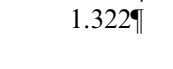 & 2.78 & 3.117 & 1.028 & 2.54 & 2.795 \\
\hline Summary statistics: & \multicolumn{3}{|c|}{$\begin{array}{c}\text { Log-likelihood }=244.64 \\
\chi^{2}=63.30, \mathrm{df}=9, P<0.0001\end{array}$} & \multicolumn{3}{|c|}{$\begin{array}{c}\text { Log-likelihood }=243.60 \\
\chi^{2}=64.35, \mathrm{df}=9, P<0.0001\end{array}$} \\
\hline
\end{tabular}

$\uparrow$ Computed as PERCEIVED RISK $=$ CHANCE OF WILDFIRE $\times$ CHANCE OF DAMAGE.

\$ Variable value predicted using estimated coefficients reported in Table 5.

Note: The $\S, \mid$, and $\uparrow$ indicate statistical significance at the $10 \%, 5 \%$, and $1 \%$ levels, respectively.

Fig. 4. Probability of completing mitigation behavior across the full study area over 50 simulated years in Envision under three management scenarios.

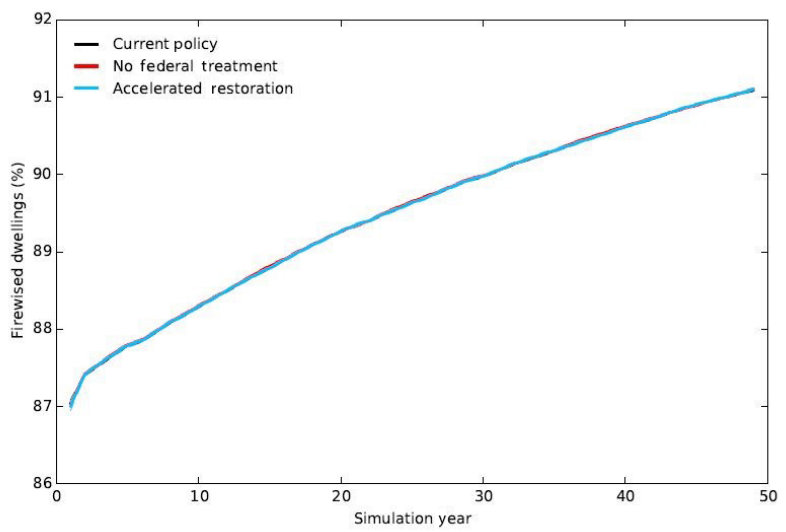

\section{DISCUSSION AND CONCLUSION}

We have estimated empirical models that examine the influence of biophysical and socioeconomic factors on homeowners' wildfire risk perceptions and risk mitigation actions, with a focus on biophysical measures of wildfire risk components, including the likelihoods of wildfire and damage to the home. This work builds on recent studies (e.g., Champ et al. 2013, Fischer et al. 2014, Dickinson et al. 2015, Wolters et al., personal communication) in a number of ways by (1) examining the two components of risk discretely, (2) examining the influence of biophysical (or landscape) variables on both homeowners' wildfire risk perceptions and mitigation behavior, (3) using two
Fig. 5. Year 50 biophysical and mitigation behavior variable variation around Sunriver, Oregon. $(\mathrm{WUI}=$ wildland-urban interface)

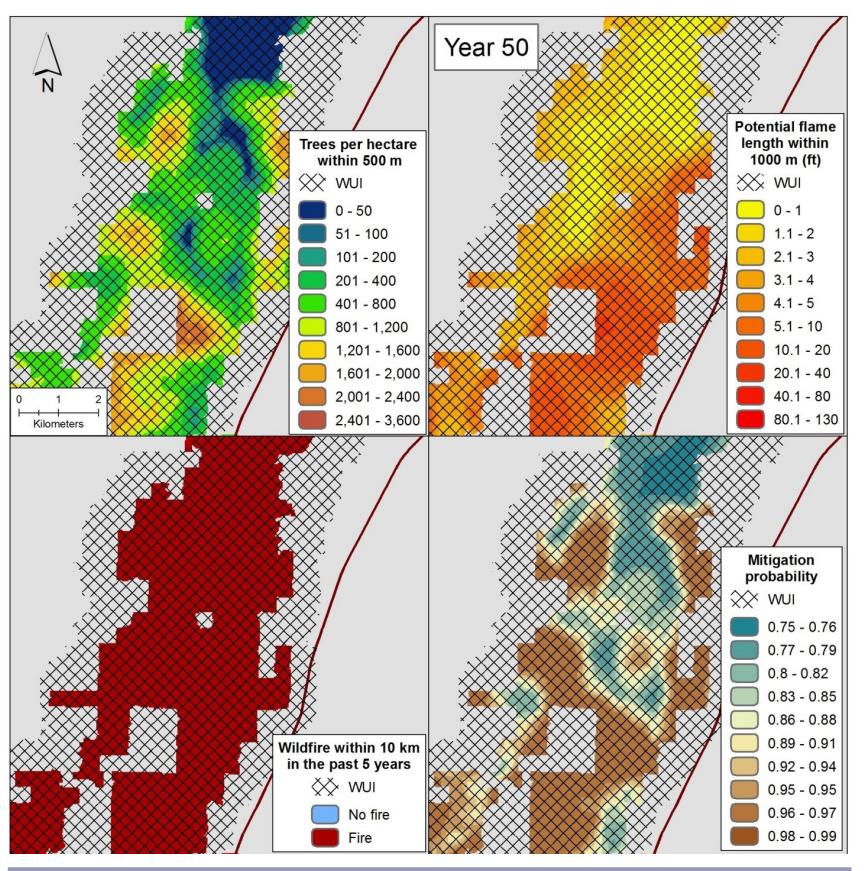

methods for measuring mitigation, (4) using sensitivity analysis to identify which variables have the greatest potential to change mitigation output in the model, and (5) demonstrating how such analysis can enable visualizing mitigation likelihoods at landscape scales under different management scenarios. Additionally, the 
Table 7. Sensitivity analysis showing predicted values $\dagger$ of CHANCE OF WILDFIRE, CHANCE OF DAMAGE, and MITIGATION when setting individual biophysical explanatory variables at their sample minimum, maximum, and mean values (see Table 2).

\begin{tabular}{|c|c|c|c|}
\hline \multirow[b]{2}{*}{ Explanatory variables } & \multicolumn{3}{|c|}{ Explanatory variable held at: } \\
\hline & Minimum & Mean & Maximum \\
\hline \multicolumn{4}{|l|}{ CHANCE OF WILDFIRE predicted values: +} \\
\hline BURN PROBABILITY & 0.950 & 0.973 & 0.995 \\
\hline WILDFIRE WITHIN MILES & 0.910 & 0.973 & 0.983 \\
\hline PRESCRIBED BURN WITHIN MILES & 0.932 & 0.973 & 0.981 \\
\hline \multicolumn{4}{|l|}{ CHANCE OF DAMAGE predicted values: $\dagger$} \\
\hline CONDITIONAL FLAME LENGTH & 0.042 & 0.106 & 0.652 \\
\hline TREES PER HECTARE & 0.046 & 0.106 & 0.967 \\
\hline WILDFIRE WITHIN MILES & 0.032 & 0.106 & 0.164 \\
\hline PRESCRIBED BURN NEAR & 0.085 & 0.106 & 0.190 \\
\hline \multicolumn{4}{|l|}{ NEIGHBORHOOD } \\
\hline \multicolumn{4}{|l|}{ MITIGATION predicted values: $t$} \\
\hline WILDFIRE WITHIN NEIGHBORHOOD & 0.791 & 0.831 & 0.953 \\
\hline BURN PROBABILITY & 0.831 & 0.831 & 0.832 \\
\hline WILDFIRE WITHIN MILES & 0.808 & 0.831 & 0.848 \\
\hline PRESCRIBED BURN WITHIN MILES & 0.830 & 0.831 & 0.832 \\
\hline CONDITIONAL FLAME LENGTH & 0.812 & 0.831 & 0.939 \\
\hline TREES PER HECTARE & 0.813 & 0.831 & 0.968 \\
\hline PRESCRIBED BURN NEAR & 0.825 & 0.831 & 0.855 \\
\hline \multicolumn{4}{|l|}{ NEIGHBORHOOD } \\
\hline \multicolumn{4}{|c|}{ Global minimum, mean, and maximum predicted values:§ } \\
\hline CHANCE OF WILDFIRE & 0.676 & 0.973 & 0.998 \\
\hline CHANCE OF DAMAGE & 0.004 & 0.106 & 0.999 \\
\hline MITIGATION & 0.752 & 0.831 & 0.993 \\
\hline
\end{tabular}

inclusion of homeowner risk assessments and (expert) model output risk assessments provides an interesting comparison. Our analysis illustrates one way to represent landowner behavior in agent-based models of fire-prone landscapes (Kline, White, Fischer et. al., unpublished manuscript). It also provides an empirical application and example of the conceptual framework outlined by Ager et al. (2015) for incorporating socioeconomic data and analysis into biophysical assessment of wildfire risk and mitigation opportunities at the fireshed scale.

Earlier work by McCaffrey et al. (2011) found that homeowners' wildfire risk perceptions dropped after they completed mitigation actions, which suggests that the individuals were cognizant that the altered landscape was at decreased risk of fire. Our findings support this notion; though participants tended to overestimate risk by several orders of magnitude ( $21 \%$ from surveys versus $0.3 \%$ from biophysical models), we found homeowners' wildfire risk perceptions to be positively correlated with hazardous fuel conditions predicted by fuel models as well as past experience with wildfire. This indicates that actual hazard conditions can be a significant determinant in risk perceptions. Specifically, homeowners' perceived chance of wildfire was positively correlated with the modeled probability of wildfire, while their perceived chance of damage to the home was positively correlated with modeled potential wildfire intensity and tree density. Although many managers may believe that homeowners do not take risk mitigation actions because they misunderstand biophysical risk (e.g., Gordon et al. 2012), our results indicate that the homeowners examined in our study may be savvy observers of landscape conditions and wildfire events, and that these "landscape feedbacks" enhance homeowners' concerns about wildfire hazard and motivate them to take mitigation action. This also suggests that homeowners may be considering proximate properties when making mitigation decisions, as the landscape variables used in this study employed means for the surrounding $1-\mathrm{km}$ area. In other words, if a neighbor mitigates, it is possible an individual may not mitigate on their own property because they have perceived a reduction in risk. This warrants more investigation into how proximate landscape conditions need to be to affect perceived risk.

We found advice from friends, family, and local government agencies to have little if any influence on wildfire risk perceptions among the homeowners we examined. However, advice from local government and fire awareness groups appears to have a positive influence on whether homeowners undertake risk mitigation activities. In other words, information on the risks of wildfire may not lead to an increased perception of risk, but information on how to mitigate risks may lead to completion of mitigation behaviors. This supports earlier work by Dickinson et al. (2015) that suggested receiving fire-related information from "experts" was positively associated with both structural and vegetation mitigation behaviors. Others have found similar relationships between fire-related information sources and mitigation behavior (Hall and Slothower 2009, Brenkert-Smith et al. 2012, Champ et al. 2013), while one team found that simply being familiar with 
the Community Wildfire Protection Plan was enough to increase the likelihood of completing mitigation actions (Wolters et al., personal communication).

Although policy-makers generally express concern about people choosing to live in fire-prone landscapes, evidence from our study and others (e.g., McCaffrey and Olsen 2012, Toman et al. 2013) generally suggests that a general awareness of the likelihood of wildfire risk exists among many residents in fire-prone landscapes, and that these residents likely are making a calculated and relatively informed choice to live in fire-prone landscapes. For example, our respondents were largely long-term residents who had been exposed to a wildfire or prescribed fire before. Additionally, the perceived probability and potential damage from wildfire was quite high in our sample, considerably higher than the probability and severity of potential fires as predicted by fire models (Ager et al. 2013), though this may be partially explained by our use of general terms in the survey questions (i.e., participants were asked to consider the forests closest to their homes when answering the questions - there was no prerequisite fire size or distance). However, our results also suggest that among the components of wildfire risk-likelihood of wildfire versus likelihood of damage - it is homeowners' perceptions of the likelihood of damage that may be most sensitive to biophysical measures of potential wildfire intensity, if not necessarily likelihood. Policy-makers seeking to influence increased mitigation behavior among homeowners may contribute toward this by improving homeowners' awareness of their chance of experiencing damage to the home site should a wildfire occur, as well as what measures homeowners can reasonably take to address this. This knowledge component is evident in the fire experience, perceived risk, and information source variables' associations with mitigation. Our results also suggest that policy-makers may encourage greater mitigation compliance by supporting HOA rules for reducing fuels on private property. In short, HOA rules and targeted programs to provide access to information so homeowners can assess risk, and physically, financially, and legally accomplish the mitigation work could help improve mitigation compliance.

Finally, the challenges of working with nested analysis procedures, multiple models, and a large landscape are worthy of discussion. The single largest challenge from a social scientist's perspective was the multiple assumptions that had to be made at several steps in the project. For example, while we had individual data from homeowners across the landscape that allowed for a nested regression analysis, programming Envision to model homeowner behavior involved inserting constants where our data suggested that dynamic variables would have been more appropriate (e.g., burn probability, advice from various social groups). However, the computational limitations presented by Envision dictated the format by which we could influence the large model. Other assumptions not uncommon to large CHANS projects were also challenging (e.g., that we can predict future human behavior without foreknowledge of shifts in societal norms or significant surprise events). A challenge specific to the scale of this project was that the land area was large enough that individual or even group behaviors caused little if any change in the outcomes for the larger landscape. In other words, homeowners may have been the most numerous actor type on this landscape, but they owned a comparatively small land area. Hence, an increase in mitigation behavior on homeowner properties would not be expected to make a sizable impact on large tracts of federal land, for example. To combat this challenge, we focused in on smaller areas to see smaller scale shifts in both biophysical and social behavior variables (see Figs. 3 and 5). Additionally, because the land area was so large and covered numerous smaller communities, examining the overall averages of mitigation behavior across the entire landscape showed no difference in mitigation behavior despite very different biophysical trajectories (Fig. 4). This can likely be explained by understanding that changes happened on smaller scales (Figs. 3 and 5) but may not be visible when averaged across the large landscape.

Limitations of this study, though minimized to the extent possible, do exist. We acknowledge that a higher response rate could strengthen our confidence in generalizing beyond the study sample. Future research might employ a different survey administration method (e.g., drop-off and pick-up) as an attempt to increase response rate. We also recognize that by asking respondents to recall actions and events over the last 5 years that we may be introducing some recall bias. Employing a longitudinal design that incorporated biophysical data would strengthen our prediction abilities for modeled biophysical risk and mitigation behaviors. It would be interesting to explore qualitative data aimed at explaining the various risk and mitigation findings from this survey as a follow-up to this study and with these participants. A future step could also be to build the larger, landscape model to be better able to handle more dynamic variables (i.e., less constants). Now that we have a basic model that seems to work as anticipated, we are now in a position to increase the number of dynamic variables in order to better represent the fluid human reality.

We offer the following caveats. Perhaps most important is recognition that measuring mitigation is tricky and imperfect. There are multiple methods for doing this, each with strengths and weaknesses, which we tried to at least mediate by using two methods. Second, this study and most studies rely on selfreporting, which has inherent flaws in memory recall and the tendency to be biased toward positive response (i.e., making yourself look good). Third, while we are attempting to understand mitigation behavior, we are not actually measuring behavior. Rather, we are looking at intent. This can seem a shortfall; however, barring the time and funds to actually monitor each individual's behavior over time, measuring intent to mitigate is a good proxy. Fourth, though we found biophysical variables to have some influence on mitigation via perceived risk, it was a weakly significant relationship, and other variables were more predictive. Still, this relationship with biophysical variables and perceptions of risk may warrant consideration in future research and policy.

An outcome of our empirical models is to enable the development of landscape models that can explore how homeowners' mitigation activities might vary over space and time and under different fire and management scenarios. In particular, building on work by Champ et al. (2013), our empirical models demonstrate the influence that biophysical landscape characteristics play in shaping homeowners' wildfire risk perceptions and motivating them to take mitigation actions. This can be useful in a fire management context by enabling landscape 
managers to identify places where landowners and homeowners are most likely to conduct mitigation actions and where they may need greater incentives (Ager et al. 2015). More broadly, social science information, such as we have developed here, can play a role in landscape-level mitigation planning and implementation efforts. Integration of biophysical wildfire risk metrics with information that characterizes likely landowner behavior enables managers and local officials to identify areas of both need and opportunity in terms of private landowner and homeowner cooperation with landscape-level mitigation efforts. Ideally, such integration would enable a leveraging of mitigation effort by identifying where mitigating risk most effectively involves activities conducted by public agencies and which are focused on treating biophysical conditions, such as forest fuel, versus encouraging activities conducted by private landowners and which are focused on individual home sites.

Responses to this article can be read online at: http://www.ecologyandsociety.org/issues/responses. $\mathrm{php} / 9054$

\section{Acknowledgments:}

This work was supported by the National Science Foundation Coupled Natural-Human Systems Program (NSF Grant CNH-1013296). We acknowledge our team leaders, Thomas Spies of the USDA Forest Service, Pacific Northwest Research Station, and John Bolte of Oregon State University. We thank Brent Steel and his research team for administering the survey. Finally, we thank all the homeowners for taking the time to share their views and opinions with us.

\section{LITERATURE CITED}

Ager, A. A., M. Buonopane, A. Reger, and M. A. Finney. 2013. Wildfire exposure analysis on the National Forests in the Pacific Northwest, USA. Risk Analysis 33(6):1000-1020. http://dx.doi. org/10.1111/j.1539-6924.2012.01911.X

Ager, A. A., J. D. Kline, and A. P. Fischer. 2015. Coupling the biophysical and social dimensions of wildfire risk to improve wildfire mitigation planning. Risk Analysis 35(8):1393-1406. http://dx.doi.org/10.1111/risa.12373

Ager, A. A., N. M. Vaillant, and M. A. Finney. 2010. A comparison of landscape fuel treatment strategies to mitigate wildland fire risk in the urban interface and preserve old forest structure. Forest Ecology and Management 259:1556-1570. http:// dx.doi.org/10.1016/j.foreco.2010.01.032

Bihari, M., and R. Ryan. 2012. Influence of social capital on community preparedness for wildfires. Landscape and Urban Planning 106(3):253-261. http://dx.doi.org/10.1016/j. landurbplan.2012.03.011

Blanchard, B., and R. Ryan. 2007. Management the wildland urban interface in the Northeast: perceptions of fire risk and hazard. Northern Journal of Applied Forestry 24(3):203-208.

Bolte, J. P., D. W. Hulse, S. V. Gregory, and C. Smith. 2007. Modeling biocomplexity - actors, landscapes and alternative futures. Environmental Modelling \& Software 22(5):570-579. http://dx.doi.org/10.1016/j.envsoft.2005.12.033

Brenkert-Smith, H., P. A. Champ, and N. Flores. 2006. Insights into wildfire mitigation decisions among wildland-urban interface residents. Society \& Natural Resources 19:759-768. http://dx.doi.org/10.1080/08941920600801207

Brenkert-Smith, H., P. A. Champ, and N. Flores. 2012. Trying not to get burned: understanding homeowners' wildfire riskmitigation behaviors. Environmental Management 50:1139-1151. http://dx.doi.org/10.1007/s00267-012-9949-8

Brenkert-Smith, H., K. L. Dickinson, P. A. Champ, and N. Flores. 2013. Social amplification of wildfire risk: the role of social interactions and information sources. Risk Analysis 33(5):800 817. http://dx.doi.org/10.1111/j.1539-6924.2012.01917.x

Bright, A. D., and R. T. Burtz. 2006. Firewise activities of fulltime versus seasonal residents in the wildland-urban interface. Journal of Forestry 104:307-315.

Byram, G. M. 1959. Combustion of forest fuels. Pages 61-89 in K. P. Davis, editor. Forest fire: control and use. McGraw-Hill, New York, USA.

Caulkin, D. E., J. D. Cohen, M. A. Finney, and M. P. Thompson. 2014. How risk management can prevent future wildfire disasters in the wildland-urban interface. Proceedings of the National Academy of Sciences of the United States of America 111(2):746751. http://dx.doi.org/10.1073/pnas.1315088111

Champ, P. A., G. H. Donovan, and C. M. Barth. 2013. Living in a tinderbox: wildfire risk perceptions and mitigating behaviours. International Journal of Wildland Fire 22:832-840. http://dx.doi. org/10.1071/WF12093

Cohn, P. J., D. R. Williams, and M. S. Carroll. 2008. Wildlandurban interface residents' views on risk and attribution. Pages 23 43 in W. E. Martin, C. Raish, and B. Kent, editors. Wildfire risk: human perceptions and management implications. Resources for the Future, Washington, D.C., USA.

Collins, T. W. 2008. What influences hazard mitigation? Household decision making about wildfire risks in Arizona's White Mountains. Professional Geographer 60(4):508-526. http:// dx.doi.org/10.1080/00330120802211737

Collins, T. W. 2009. Influences on wildfire hazard exposure in Arizona's high country. Society \& Natural Resources 22:211-229. http://dx.doi.org/10.1080/08941920801905336

Cortner, H. J., and R. D. Gale. 1990. People, fire, and wildland environments. Population and Environment 11(4):245-257. http:// dx.doi.org/10.1007/bf01256458

Dickinson, K., H. Brenkert-Smith, P. Champ, and N. Flores. 2015. Catching fire? Social interactions, beliefs, and wildfire risk mitigation behaviors. Society \& Natural Resources 28:807-824. http://dx.doi.org/10.1080/08941920.2015.1037034

Dillman, D. A., J. D. Smyth, and L. M. Christian. 2014. Internet, phone, mail, andmixed-mode surveys: the Tailored Design Method. Wiley, Hoboken, New Jersey, USA.

Finney, M. A. 2002. Fire growth using minimum travel time methods. Canadian Journal of Forest Research 32:1420-1424. http://dx.doi.org/10.1139/x02-068 
Finney, M. A, I. C. Grenfell, and C. W. McHugh. 2009. Modeling large fire containment using generalized linear mixed model analysis. Forest Science 55:249-255.

Finney, M. A., C. W. McHugh, I. C. Grenfell, K. L. Riley, and K. C. Short. 2011. A simulation of probabilistic wildfire risk components for the continental United States. Stochastic Environmental Research and Risk Assessment 25:973-1000. http:// dx.doi.org/10.1007/s00477-011-0462-z

Fischer, A. P. 2011. Reducing hazardous fuels on nonindustrial private forests: factors influencing landowner decisions. Journal of Forestry 109:260-266.

Fischer, A. P., J. D. Kline, A. A. Ager, S. Charnley, and K. A. Olsen. 2014. Objective and perceived wildfire risk and its influence on private forest landowners' fuel reduction activities in Oregon's (USA) ponderosa pine ecoregion. International Journal of Wildland Fire 23:143-153. http://dx.doi.org/10.1071/WF12164

Gebert, K. M., D. E. Calkin, and J. Yoder. 2007. Estimating suppression expenditures for individual large wildland fires. Western Journal of Applied Forestry 22(3):188-196.

Gordon, J. S., A. Luloff, and R. C. Stedman. 2012. A multisite qualitative comparison of community wildfire risk perceptions. Journal of Forestry 110(2):74-78. http://dx.doi.org/10.5849/ jof.10-086

Government Accounting Office (GAO). 2005. Protecting structures and improving communication during wildland fires: a report to congressional requesters. GAO-05-380. Government Accounting Office, Washington, D.C., USA.

Greene, W. H. 2012. Econometric analysis. Prentice Hall, New York, New York, USA.

Hall, T. E., and M. Slothower. 2009. Cognitive factors affecting homeowners' reactions to defensible space in the Oregon Coast Range. Society \& Natural Resources 22:95-110. http://dx.doi. org/10.1080/08941920802392187

Kasperson, R. E., O. Renn, P. Slovic, H. S. Brown, J. Emel, R. Goble, J. X. Kasperson, and S. Ratick. 1988. The social amplification of risk: a conceptual framework. Risk Analysis 8 (2):177-187. http://dx.doi.org/10.1111/j.1539-6924.1988.tb01168. $\underline{\mathrm{x}}$

Kyle, G. T., G. L. Theodori, J. D. Absher, and J. Jun. 2010. The influence of home and community attachment on Firewise behavior. Society \& Natural Resources 23:1075-1092. http://dx. doi.org/10.1080/08941920902724974

Liang, J., D. E. Calkin, K. M. Gebert, T. J. Venn, and R. P. Silverstein. 2008. Factors influencing large wildland fire suppression expenditures. International Journal of Wildland Fire 17:650-659. http://dx.doi.org/10.1071/WF07010

Lindell, M. K., and C. S. Prater. 2000. Household adoption of seismic hazard adjustments: a comparison of residents in two states. International Journal of Mass Emergencies and Disasters 18(2):461-501.

Martin, W. E., I. M. Martin, and B. Kent. 2009. The role of risk perceptions in the risk mitigation process: the case of wildfire in high risk communities. Journal of Environmental Management 91:489-498. http://dx.doi.org/10.1016/j.jenvman.2009.09.007
McCaffrey, S. 2004. Thinking of wildfire as a natural hazard. Society \& Natural Resources 17:509-516. http://dx.doi. org/10.1080/08941920490452445

McCaffrey, S. M. 2006. The public and wildland fire management: social science findings for managers. General Technical Report NRS-1, U.S. Department of Agriculture, Forest Service, Northern Research Station, Newtown Square, Pennsylvania, USA. http://dx.doi.org/10.2737/nrs-gtr-1

McCaffrey, S. 2008. Understanding public perspectives of wildfire risk. Pages 11-22 in W. E. Martin, C. Raish, and B. Kent, editors. Wildfire risk: human perceptions and management implications. Resources for the Future, Washington, D.C., USA.

McCaffrey, S. M., and C. S. Olsen. 2012. Research perspectives on the public and fire management: a synthesis of current social science on eight essential questions. General Technical Report NRS-104, U.S. Department of Agriculture, Forest Service, Northern Research Station, Newtown Square, Pennsylvania, USA. http:// dx.doi.org/10.2737/nrs-gtr-104

McCaffrey, S. M., M. Stidham, E. Toman, and B. Shindler. 2011. Outreach programs, peer pressure, and common sense: What motivates homeowners to mitigate wildfire risk? Environmental Management 48:475-488. http://dx.doi.org/10.1007/s00267-011-9704-6

McFarlane, B. L., T. K. McGee, and H. Faulkner. 2011. Complexity of homeowner wildfire risk mitigation: an integration of hazard theories. International Journal of Wildland Fire 20:921931. http://dx.doi.org/10.1071/WF10096

McGee, T. K., B. L. McFarlane, and J. Varghese. 2009. An examination of the influence of hazard experience on wildfire risk perceptions and adoption of mitigation measures. Society \& Natural Resources 22:308-323. http://dx.doi.org/10.1080/08941920801910765

McNeill, I. M., P. D. Dunlop, J. B. Heath, T. C. Skinner, and D. L. Morrison. 2013. Expecting the unexpected: predicting physiological and psychological wildfire preparedness from perceived risk, responsibility, and obstacles. Risk Analysis 33 (10):1829-1843. http://dx.doi.org/10.1111/risa.12037

National Interagency Fire Center. 2014. Federal firefighting costs (suppression only). [online] URL: http://www.nifc.gov/fireInfo/ fireInfo documents/SuppCosts.pdf

Nelson, K. C., M. C. Monroe, and J. F. Johnson. 2005. The look of the land: homeowner landscape management and wildfire preparedness in Minnesota and Florida. Society \& Natural Resources 18(4):321-336. http://dx.doi.org/10.1080/08941920590915233

Nelson, K. C., M. C. Monroe, J. F. Johnson, and A. Bowers. 2004. Living with fire: homeowner assessment of landscape values and defensible space in Minnesota and Florida, USA. International Journal of Wildland Fire 13:413-425. http://dx.doi.org/10.1071/ $\underline{\mathrm{WF} 03067}$

Ohmann, J. L., and M. J. Gregory. 2002. Predictive mapping of forest composition and structure with direct gradient analysis and nearest-neighbor imputation in coastal Oregon, U.S.A. Canadian Journal of Forest Research 32(4):725-741. http://dx.doi.org/doi. org/10.1139/x02-011

Radeloff, V. C., R. B. Hammer, S. I. Stewart, J. S. Fried, S. S. Holcomb, and J. F. McKeefry. 2005. The wildland-urban 
interface in the United States. Ecological Applications 15:799-805. http://dx.doi.org/10.1890/04-1413

Renn, O., W. J. Burns, J. X. Kasperson, R. E. Kasperson, and P. Slovic. 1992. The social amplification of risk: theoretical foundations and empirical applications. Journal of Social Issues 48(4):137-160. http://dx.doi.org/10.1111/j.1540-4560.1992.tb01949. $\underline{\mathrm{x}}$

Rogers, R. W. 1983. Cognitive and physiological processes in fear appeals and attitude change: a revised theory of protection motivation. Pages 153-176 in J. T. Cacioppo and R. E. Petty, editors. Social Psychophysiology: a Source Book. Guilford Press, New York, USA.

Rollins, M. G. 2009. LANDFIRE: a nationally consistent vegetation, wildland fire, and fuel assessment. International Journal of Wildland Fire 18:235-249. http://dx.doi.org/10.1071/ WF08088

Schulte, S., and K. A. Miller. 2010. Wildfire risk and climate change: the influence on homeowner mitigation behavior in the wildland-urban interface. Society \& Natural Resources 23:417435. http://dx.doi.org/10.1080/08941920903431298

Scott, H. J., and R. E. Burgan. 2005. Standard fire behavior fuel models: a comprehensive set for us with Rothermel's surface fire spread model. General Technical Report RMRS-GTR-153, U.S. Department of Agriculture, Forest Service, Rocky Mountain Research Station, Fort Collins, Colorado, USA.

Short, K. C. 2015. Spatial wildfire occurrence data for the United States, 1992-2013 [FPA_FOD_20150323]. Third edition. Forest Service Research Data Archive, Fort Collins, Colorado, USA. http://dx.doi.org/10.2737/RDS-2013-0009.3

Showalter, P. S. 1993. Prognostication of doom: an earthquake prediction's effect on four small communities. International Journal of Mass Emergencies and Disasters 11:279-292.

SILVIS Lab. 2017. WIldland-urban interface. University of Wisconsin-Madison, Madison, Wisconsin, USA. [online] URL: http://silvis.forest.wisc.edu/content/wildland-urban-interface-standalone

Spies, T. A., E. White, A. Ager, J. D. Kline, J. P. Bolte, E. K. Platt, K. A. Olsen, R. J. Pabst, A. M.G. Barros, J. D. Bailey, S. Charnley, J. Koch, M. M. Steen-Adams, P. H. Singleton, J. Sulzman, C. Schwartz, and B. Csuti. 2017. Using an agent-based model to examine forest management outcomes in a fire-prone landscape in Oregon, USA. Ecology and Society 22(1):25. https://doi. org/10.5751/ES-08841-220125

Spies, T. A., E. M. White, J. D. Kline, A. P. Fischer, A. Ager, J. Bailey, J. Bolte, J. Koch, E. Platt, C. S. Olsen, D. Jacobs, B. Shindler, M. M. Steen-Adams, and R. Hammer. 2014. Examining fire-prone forest landscapes as coupled human and natural systems. Ecology and Society 19(3):9. http://dx.doi.org/10.5751/ es-06584-190309

Steelman, T. A. 2008. Addressing the mitigation paradox at the community level. Pages 64-80 in W. E. Martin, C. Raish, and B. Kent, editors. Wildfire risk: human perceptions and management implications. Resources for the Future, Washington, D.C., USA.
Syphard, A. D., T. J. Brennan, and J. E. Keeley. 2014. The role of defensible space for residential structure protection during wildfires. International Journal of Wildland Fire 23:1165-1175.

Toman, E., M. Stidham, S. McCaffrey, and B. Shindler. 2013. Social science at the wildland-urban interface: a compendium of research results to create fire-adapted communities. General Technical Report NRS-GTR-111, U.S. Department of Agriculture, Forest Service, Northern Research Station, Newtown Square, Pennsylvania, USA. http://dx.doi.org/10.2737/ $\underline{\text { nrs-gtr-111 }}$

United States Census Bureau. 2015. QuickFacts. [online] URL: https://www.census.gov/quickfacts/

United States Department of Agriculture (USDA), Forest Service. 2009. America's forests health update 2009. [online] URL: http://www.fs.fed.us/foresthealth/publications/foresthealthupdate2009. $\underline{\mathrm{pdf}}$

United States Department of Agriculture, Office of the Inspector General (USDA OIG). 2006. Audit report: Forest Service large fire suppression costs. Report Number 08601-44-SF, Washington, D.C., USA.

Winter, G., S. M. McCaffrey, and C. A. Vogt. 2009. The role of community policies in defensible space compliance. Forest Policy and Economics 11(8):570-578. http://dx.doi.org/10.1016/j. forpol.2009.07.004

Zachariassen, J., K. F. Zeller, N. Nikolov, and T. McClelland. 2003. A review of the Forest Service remote automated weather station (RAWS) network. General Technical Report RMRSGTR-119, U.S. Department of Agriculture, Forest Service, Rocky Mountain Research Station, Fort Collins, Colorado, USA. 


\section{Appendix 1: Constructing independent variables to represent wildfire likelihood and potential intensity}

We developed two explanatory variables to approximate survey respondents' actual exposure to wildfire of risk using outputs from the wildfire simulation model FSIM and methods described by Finney and colleagues (Finney et al. 2011). The FSIM program generates wildfire scenarios for a large number (e.g., 50,000) of hypothetical wildfire seasons using relationships between historical Energy Release Component (ERC) and fire occurrence. The ERC and other weather data are derived from weather records that span between 10 and 20 years and were collected as part of the network of automated weather stations (RAWS) (Zachariassen et al. 2003). The simulations operate on a daily time step and the daily probability of a fire was predicted by logistic regression of historical fire occurrence and ERC. Once a fire is ignited, the daily weather is generated using the results of a time series analysis of daily RAWS weather data (Finney et al. 2011). The time series uses estimates of the seasonal trends, the autocorrelation (dependency of a day's ERC value on previous days), and the daily standard deviation to generate synthetic daily weather streams for each day of simulation. Wind data (speed by direction) were also derived from the RAWS stations and tabulated by month as a joint probability distribution and the resulting distribution was then randomly sampled to obtain daily wind data. Each fire's growth and behavior were simulated from its ignition day through the remainder of the season, or until containment was achieved as predicted based on historical large fires and their recorded sequence of daily activity (Finney et al. 2009). The containment model was developed from an analysis of the daily change in fire size to identify intervals of high spread and low spread for each fire. The containment probability model was found to be positively related to periods of low fire spread (Finney et al. 2009). Each fire's growth and behavior were simulated from its ignition day through the remainder of the season, or until containment was achieved as predicted based on historical large fires and their recorded sequence of daily activity (Finney et al. 2009).

Surface and canopy fuel data were obtained from the national LANDFIRE data grid (Rollins 2009). The surface fuel data consisted of stylized fuel models as described elsewhere (Scott et al. 2005). Validation of the fire size distribution from FSIM simulations were reported in Finney and colleagues (Finney et al. 2011). While refinements to FSIM and the input data continue within the federal wildfire management agencies, the outputs used in the current study are adequate for the study objectives. Data consisted of 240,347 ignitions that started on Forest Service land representing 20,000-50,000 fire season replicates on the 16 national forests. We assumed random ignition locations for simulated fires, consistent with FPA large fire simulation methods (Finney et al. 2011). Large fire events within the study area have primarily been caused by lightning, and there are too few large fire incidents to detect spatial patterns if they existed. Fire simulations were performed at $270 \times 270 \mathrm{~m}$ pixel resolution, a scale that permitted relatively fast simulation times and incorporated important spatial variation in fuel data. Simulations were completed on a farm of 64 bit SMP workstations located at the EROS Data Center in Sioux Falls, South Dakota.

FSIM outputs consisted of an overall burn probability and a frequency distribution of flame lengths in $0.5 \mathrm{~m}$ classes for each $270 \mathrm{~m}$ x $270 \mathrm{~m}$ pixel. Burn probability was defined as: 
where $\mathrm{B}$ is the number of times a pixel burns and $\mathrm{n}$ is the number of simulated fires. The BURN PROBABILITY for a given pixel is an estimate of the annual likelihood that a pixel will burn given a random ignition within the study area. Fire intensity (Byram 1959) is predicted by the fire spread algorithm and is dependent on the direction the fire encounters a pixel relative to the major direction of spread (i.e., heading, flanking, or backing fire), as well as slope and aspect (Finney 2002). FSIM converts fireline intensity (FI, $\mathrm{kW} \mathrm{m}^{-1}$ ) to flame length (FL, $\mathrm{m}$ ) based on Byram's (1959) equation:

$$
\mathrm{FL}=0.775(\mathrm{FI})^{0.46}
$$

The flame length distribution generated from multiple fires burning each pixel was used to calculate CONDITIONAL FLAME LENGTH as:

$$
\text { CONDITIONAL FLAME LENTH }=\sum_{\mathrm{i}=1}^{8}\left(\mathrm{BP}_{\mathrm{i}} / \text { BURN PROBABILITY }\right) *\left(\mathrm{FL}_{\mathrm{i}}\right)
$$

where $\mathrm{FL}_{\mathrm{i}}$ is the flame length midpoint of the $\mathrm{i}^{\text {th }}$ category, and $\mathrm{BP} \mathrm{i}$ is the probability of fire in flame length i. CONDITIONAL FLAME LENGTH is the probability weighted flame length given a fire occurs and is a measure of wildfire hazard (Ager et al. 2010). For each parcel we then calculated average values for BURN PROBABILITY and CONDITIONAL FLAME LENGTH for a 1-km radius of respondents' homes to develop a broader index of wildfire exposure. 
Appendix 2: Alternative regression models describing homeowner mitigation behavior.

Table A2.1. Estimated coefficients of an alternative binary logit models describing respondents self-reported likelihood of conducting mitigations activities within past five years, with biophysical explanatory variables included $(\mathrm{N}=284)$.

\begin{tabular}{cccc}
\multicolumn{2}{c}{$\begin{array}{c}\text { With respondent-reported } \\
\text { perceived risk variable }\end{array}$} & \multicolumn{2}{c}{$\begin{array}{c}\text { With model-predicted } \\
\text { risk variable }\end{array}$} \\
$\begin{array}{c}\text { Estimated } \\
\text { coefficient }\end{array}$ & $\begin{array}{c}\text { Wald chi- } \\
\text { squared }\end{array}$ & $\begin{array}{c}\text { Estimated } \\
\text { coefficient }\end{array}$ & $\begin{array}{c}\text { Wald chi- } \\
\text { squared }\end{array}$ \\
-0.217 & 0.07 & -0.152 & 0.04 \\
$1.362^{*}$ & 3.20 & -- & -- \\
-- & -- & $2.725^{* *}$ & 4.41 \\
0.649 & 0.31 & 1.357 & 1.18 \\
-0.101 & 0.44 & -0.200 & 1.40
\end{tabular}

Constant
PERCEIVED RISK ${ }^{\dagger}$
PERCEIVED RISK ${ }^{\ddagger}$
BURN PROBABILITY
CONDITIONAL FLAM
LENGTH
WILDFIRE IN
NEIGHBORHOOD
ADVICE: FAMILY OR
NEIGHBOR

ADVICE: LOCAL

GOVERNMENT

ADVICE: LOCAL FIRE

AWARENESS GROUP

PROPERTY OWNER

TENURE

$1.573^{* *}$

5.60

$1.701^{* * *}$

0.295

0.74

0.260

0.57

AGE

HOA RULES

$$
0.937^{* * *}
$$

7.46

$0.794^{* *}$

$$
1.793^{* * *}
$$

8.08

$1.514^{* *}$

Summary statistics:

$\begin{array}{cc}1.370^{* *} & 5.71 \\ 0.030^{*} & 2.97 \\ -0.028^{* *} & 4.55 \\ 1.147^{* * *} & 7.85\end{array}$

$1.220^{* *}$
$0.029^{*}$
$-0.025^{*}$
$1.035^{* *}$

Log-likelihood $=244.17$

Log-likelihood $=241.98$ $\chi^{2}=63.78, d f=11, \mathrm{P}<0.0001$ $\chi^{2}=65.96, d f=11, \mathrm{P}<0.0001$

Note: The ${ }^{*},{ }^{* *}$, and ${ }^{* * *}$ indicate statistical significance at the $10 \%, 5 \%$ and $1 \%$ levels.

${ }^{\dagger}$ Computed as PERCEIVED RISK = PERCEIVED CHANCE OF WILDFIRE * PERCEIVED CHANCE OF DAMAGE.

$¥$ Variable value predicted using estimated coefficients reported in Table 5. 
Table A2.2. Estimated coefficients of an ordered logit model describing respondents selfreported likelihood of any of several mitigation activities ${ }^{\dagger}$ within past five years $(\mathrm{N}=246)$.

Without wildfire risk variables With wildfire risk variables

Explanatory variables

Intercept 7

Intercept 6

Intercept 5

Intercept 4

Intercept 3

Intercept 2

Intercept 1

PERCEIVED RISK

BURN PROBABILITY

CONDITIONAL FLAME

LENGTH

WILDFIRE IN

NEIGHBORHOOD

ADVICE: FAMILY OR

NEIGHBOR

ADVICE: LOCAL

GOVERNMENT

ADVICE: LOCAL FIRE AWARENESS GROUP

PROPERTY OWNER

TENURE

AGE

HOA RULES

Summary statistics:

$$
\begin{aligned}
& \text { Estimated } \\
& \text { coefficient }
\end{aligned}
$$

$$
-4.977^{* * * *}
$$

$$
-3.370^{* * * *}
$$$$
-2.566^{* * *}
$$$$
-1.853^{* * *}
$$$$
-1.073^{*}
$$

$-0.286$

0.923

$1.118^{* *}$

$--$

$--$

$0.646^{* *}$

0.382

$0.761^{* * *}$

$1.086^{* * *}$

0.373

$0.030^{* * *}$

0.007

0.014

Log-likelihood $=920.032$

$\chi^{2}=72.01, d f=9, \mathrm{P}<0.0001$

$--$

$--$
Estimated coefficient

Wald chisquared

42.84

24.28

10.91

$-3.11$

$-1.82$

$-0.49$

1.49

2.00

2.01

$0.622^{*}$

3.76

1.63

0.349

2.15

3.09

$0.760^{* * *}$

9.50

3.60

$1.069^{* * *}$

12.15

0.85

0.445

1.02

2.56

$0.028^{* *}$

5.53

0.72

0.006

0.35

0.06

0.014

0.00

Log-likelihood $=917.155$ $\chi^{2}=70.13, d f=11, \mathrm{P}<0.0001$

Note: The ${ }^{*},{ }^{* *}$, and ${ }^{* * *}$ indicate statistical significance at the $10 \%, 5 \%$ and $1 \%$ levels.

${ }^{\dagger}$ Activities include planting fire-resistant plants, planting trees and shrubs at least 15 feet apart, pruning branches of trees within 85 feet of home, reducing the density of trees within 100 feet of the home, cleaning roof, gutters, and surrounding vegetation to avoid accumulation of needles, leaves, and dead plants, stacking firewood and lumber at least 30 feet from the home, and using nonflammable building materials, such as tile, slate, or stone.

tVariable value predicted using estimated coefficients reported in Table 5. 